\title{
Chapter
}

\section{Clay/Conductive Polymer Nanocomposites}

Ali Saad ${ }^{1}$, Khouloud Jlassi ${ }^{2}$, Mária Omastová ${ }^{3}$ and Mohamed M. Chehimi ${ }^{4}$

${ }^{1}$ University of Carthage, La Marsa, Tunisia; ${ }^{2}$ Qatar University, Doha, Qatar; ${ }^{3}$ Slovak Academy of Sciences, Bratislava, Slovakia; ${ }^{4}$ Paris Est University, CNRS, Thiais, France

\section{INTRODUCTION}

Inherently conductive polymers (ICPs) are specialty polymers that conduct electricity without any addition of metallic fillers, in contrast to traditional conductive composites obtained by mixing insulating polymers with metals. The research on ICPs took off when the group of McDiarmid discovered the inherent conductivity of polyacetylene upon doping with halogens [1]. Global development has led to the Nobel Prize in Chemistry awarded to McDiarmid, Shirakawa, and Heeger in 2000 for the discovery of ICPs [2].

Since the seminal work of the Nobel Prize winners, extensive research has been conducted with other conjugated polymers such as polypyrrole (PPy), polyaniline (PANI), polythiophene (PT), and later poly(3,4-ethylenedioxythiophene) (PEDOT) (Fig. 6.1) [3].

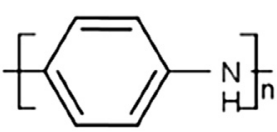

Polyaniline

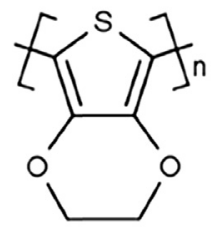

PEDOT

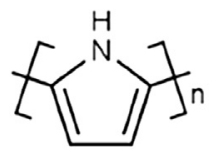

Polypyrrole

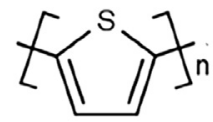

Polythiophene

FIGURE 6.1 Chemical structure of the main conjugated polymers in their neutral state

Clay-Polymer Nanocomposites. http://dx.doi.org/10.1016/B978-0-323-46153-5.00006-9

Copyright @ 2017 Elsevier Inc. All rights reserved. 
During the same blooming era of conductive polymers, much research was undertaken on clay-polymer nanocomposites because clays impart high specific surface area as well as reinforcement and barrier properties to polymer matrices [4-7]. It was thus logical to investigate the making of clay/ICP nanocomposites and examine their physicochemical properties.

Looking back at the developments on clay/ICP nanocomposites, much work has been achieved in electrochemistry because ICPs (e.g., PPy and PANI) can readily be prepared as thin films on metallic and carbon electrodes. To make clay/ICP nanocomposites, electrodes were coated with clay (hectorite)/PPy by electropolymerization of pyrrole in the presence of clay suspensions [8] to provide adherent or free-standing hectorite/PPy films. However, it soon became clear that electrochemistry was not suitable for mass production, whereas oxidative polymerization of conjugated monomers produces ICPs in high yields. Interestingly, this can be achieved in various media (mostly aqueous) by employing several oxidizing agents, dopants, and eventually surfactants [9]. Similarly, in the case of coatings on electrodes, research has been directed toward the making of clay/ICP nanocomposite powders [10]. These materials have many features: electrical conductivity, thermal stability, possible total exfoliation of the clay within the conductive polymer matrices, and barrier properties. In addition, they have unique applications such as conductive fillers [11], reinforcements [12], catalysts [13], antibacterial nanocomposites [14], heavy metal ion sensors [15], and controlled drug delivery systems [16].

In this chapter we will describe general methods of synthesis of clay/ICP systems by in-situ polymerization of conjugated monomers in the presence of clays or by mixing clays with prefabricated ICPs. We will restrict the chapter to PPy, PANI, PT, and PEDOT and their characteristics. For each of these conductive polymers we will detail some eye-catching, timely applications.

\section{GENERAL PREPARATIVE METHODS}

Clay/ICP nanocomposites can be prepared by various approaches. Most probably the very first trials were done by Alan Bard and coworkers who prepared nanocomposite films by electropolymerization of pyrrole on hectorite clay-coated Pt or glassy carbon electrodes [8]. The method provides adherent films that can be detached from the electrodes. However, chemical oxidative polymerization is scalable and has been the subject of numerous studies. It is performed with pristine or organophilic clays to improve wetting and adhesion of the ICPs to the underlying clay [17]. 
Usually, polymerization in the presence of organophilic clays yields clay/ICP nanocomposites with higher conductivity than the reference nanocomposite prepared with hydrophilic, pristine clay. This is because of (1) a better intercalation and eventually exfoliation of the clay, and (2) in particular, an excellent wetting of the lamellae by continuous conductive polymer monolayers.

Photopolymerization uses photosensitizers such as $\mathrm{AgNO}_{3}, \mathrm{AuCl}_{3}$, and $\mathrm{CuCl}_{2}$ [18]. Upon exposure to $\mathrm{UV}$ light, $\mathrm{Ag}^{+}$(taken as an example) strips an electron from the conjugated monomer and reduces to metallic silver nanoparticles (AgNPs), while the oxidized monomer undergoes polymerization. For the $\mathrm{AgNO}_{3} /$ pyrrole system there is an interest in conducting photopolymerization because it reduces the time of preparation from 2 days to $2-3 \mathrm{~h}$ or even much less, as claimed by Zang et al. [14]. Photopolymerization could be conducted with $\mathrm{AuCl}_{3}$ but in our own experience we noted immediate oxidative polymerization of pyrrole upon contact with $\mathrm{AuCl}_{3}$. For PANI, the benefit is marginal because photopolymerization must be conducted over $6 \mathrm{~h}$, still lower than the usual time set of 12-24 h [19].

Surprisingly, to the very best of our knowledge, sonochemical preparation of clay/ICP nanocomposites has not been conducted despite its efficiency and rapidity for making polymer nanocomposites, including those of PPy and PANI [20].

\section{CLAY/POLYPYRROLE NANOCOMPOSITES}

\subsection{Synthesis, Characterization, Morphology, and Potential Applications}

\subsubsection{Electropolymerization}

An excellent review by Sadki et al. [21] summarized the knowledge of mechanisms of pyrrole electropolymerization. The most accepted mechanism is depicted in Fig. 6.2.

After electrooxidation of the monomer at anodic potential $E_{\mathrm{pa}}$, radical cations form dimers that lose protons and are further oxidized at lower potential than those of a single monomer. The mechanism continues until formation of the final polymer chain with higher repeat units. The final polymer exhibits one positive charge for each 3-4 pyrrole repeat units.

Electropolymerization can be conducted in two ways to prepare clay/PPy films: (i) on a clay-coated electrode, or (ii) in a clay suspension therefore leading to the codeposition of clay and PPy (Fig. 6.3). 


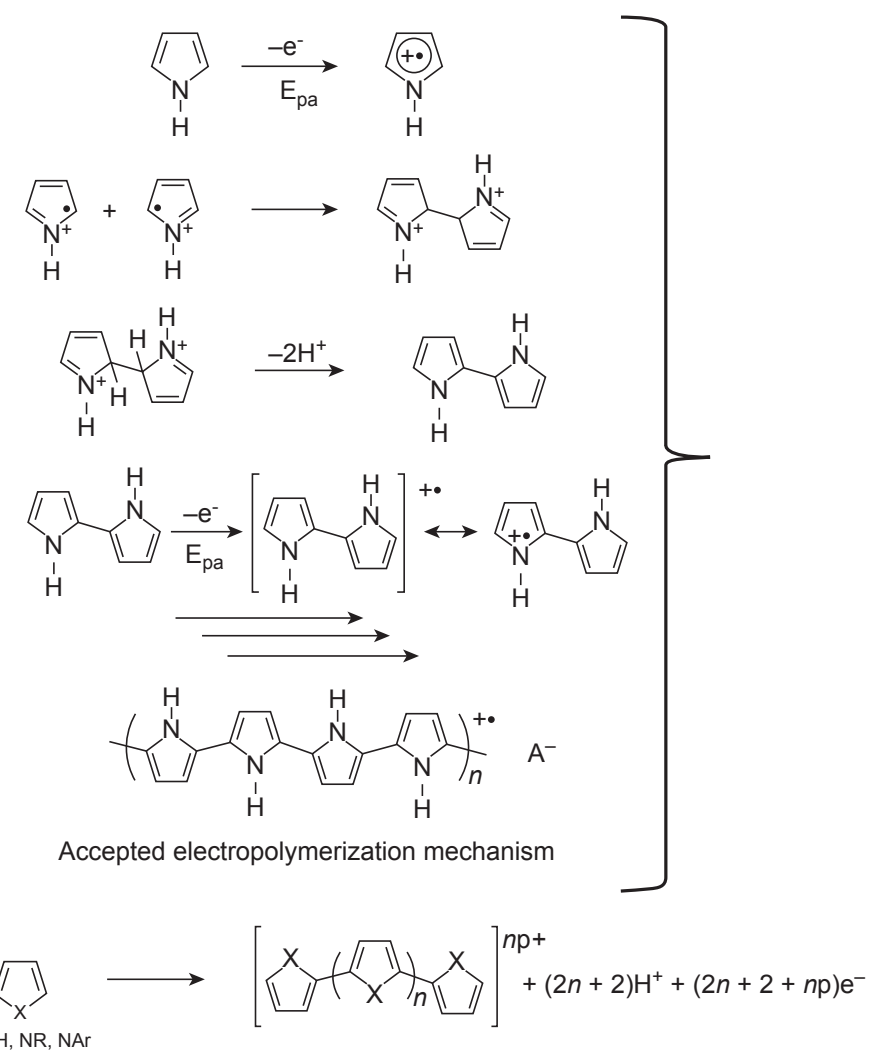

Balanced overall chemical equation

FIGURE 6.2 Accepted electropolymerization of pyrrole (upper panel) and balanced overall electropolymerization (lower panel). A is the anion that counterbalances the positive charge of polypyrrole. Reproduced and adapted with permission of RSC from S. Sadki, P. Schottland, N. Brodie, G. Sabouraud, Chem. Soc. Rev. 29 (2000) 283-293.

The procedures displayed in Fig. 6.3 were conducted on platinum and glassy carbon electrodes in either water or acetonitrile. Thick free-standing films were obtained and detached from the electrodes; they exhibited superior stability compared to PPy [8]. A variant of method (i) displayed in Fig. 6.3 was proposed by Trueba et al. [22]: pyrrole was first loaded in pristine and acid-treated montmorillonite (MMT) and in zeolite, then the inorganic/pyrrole hybrids were immobilized on a Pt electrode from a mixture of colloidal dispersions and a tetrahydrofuran solution of polystyrene (PS). Electropolymerization was conducted in aqueous solution and led to the formation of PPy nanowires in the host proton-modified natural zeolite clinoptilolite. It was concluded that PPy synthesis with electrochemical activity is favored in a strong acidic nanoscaled environment lattice. 


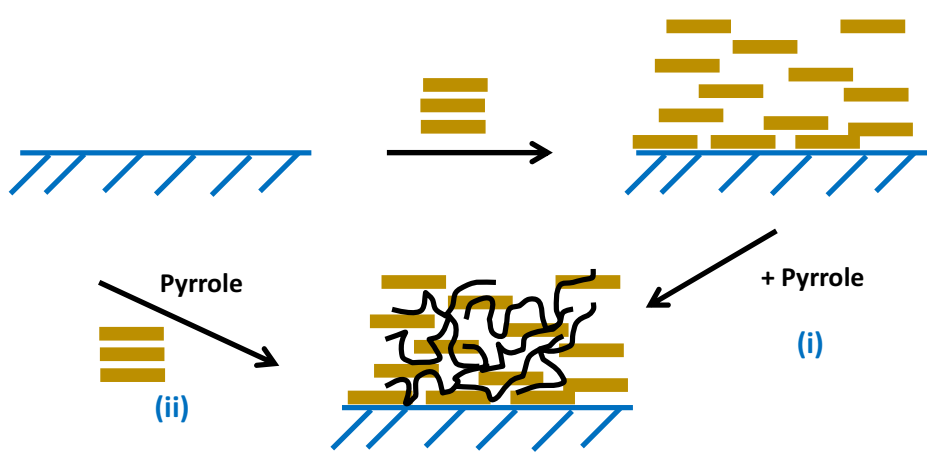

FIGURE 6.3 Schematic illustration of the electrochemical preparation methods of clay/polypyrrole (PPy) nanocomposites by electrosynthesis of PPy on a clay-coated electrode (i), and by electropolymerization of pyrrole in the presence of a clay colloidal suspension (ii).

Similarly, a composite film of laponite-nitrate reductase-poly(pyrroleviologen) was prepared in two steps: deposition of laponite-nitrate reductase on a glassy carbon disc followed by adsorption of pyrrole-viologen [23], and electropolymerization of the adsorbed pyrrole derivative in aqueous $0.1 \mathrm{M} \mathrm{LiClO}_{4}$ solution, in a second step. The resulting composite film served as the electrochemical biosensor of nitrate reduction.

In another bioelectrochemical, pyrrole was electropolymerized in phosphate buffer saline suspension of palygorskite-loaded aspirin (Pal/Asp). Palygorskite retained its Palwas fibrillar single crystal with a diameter ranging from 20 to $30 \mathrm{~nm}$; PPy was coated evenly all along the fibers in a core/shell structure. Clay provided high surface area and therefore large loading of aspirin. The electrochemical effective surface area, determined by chronocoulometry, was found to be $4.0 \mathrm{~cm}^{2}$ for the Pal/PPyAsp nanocomposite, much higher than $0.7 \mathrm{~cm}^{2}$ for PPyAsp.

The Pal/PPyAsp nanocomposite served for the release of aspirin by applying $-0.6 \mathrm{~V}$. At this potential, PPy was reduced and thus dedoped by expelling aspirin.

Fig. 6.4 shows cumulative aspirin release versus time for Pal/PPyAsp and PPyAsp with or without electrical stimulation. Higher release for the $\mathrm{Pal} / \mathrm{PPyAsp}$ is caused by the large specific surface area of the clay and its capacity of loading aspirin by electrostatic interactions between the carboxylate group in aspirin and the metal cations $\mathrm{Mg}^{2+}, \mathrm{Al}^{3+}$, and $\mathrm{Fe}^{3+}$.

\subsubsection{Oxidative Polymerization}

If electrochemical processes are seldom reported for the making of clay/PPy nanocomposites, oxidative polymerization has attracted much interest 


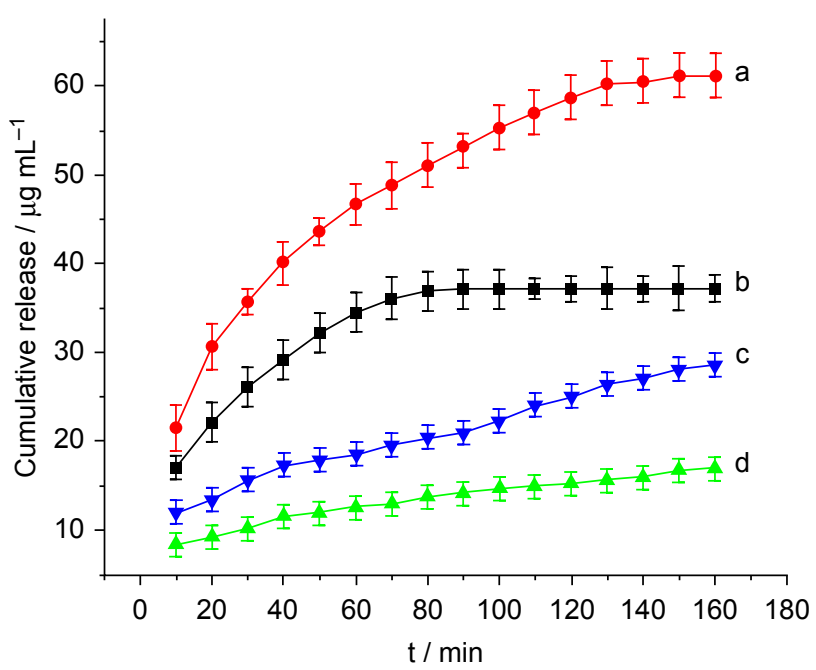

FIGURE 6.4 Cumulative aspirin release versus time. Release of aspirin from Pal/PPyAsp (a) and PPyAsp (b) by an electrical stimulus at $-0.6 \mathrm{~V}$; natural release of aspirin from Pal/PPyAsp (c) and PPyAsp (d) without any electrical stimulus. Reproduced with permission of Elsevier from Y. Kong, H. Ge, J. Xiong, S. Zuo, Y. Wei, C. Yao, L. Deng, Appl. Clay Sci. 99 (2014) 119-124.

because of its scalability and widespread applications. Indeed, nanocomposites prepared by electrochemistry are adherent and thus applicable in electrochemical processes only. Instead, nanocomposite powder particles prepared by oxidative polymerization are versatile and amenable to diverse applications encompassing catalysis, electrorheology, mechanical reinforcement, and bioactivity.

The mechanism of oxidative polymerization of pyrrole is similar to that of electropolymerization in the sense that it is based on the coupling between radical cations [24]. Herein, one has to insist that PPy is not a perfect linear polymer; instead it has substantial cross-linking, as shown in Fig. 6.5, for the synthesis of PPy in an acidic medium [25]:

In most cases, polymerization of pyrrole is conducted in aqueous solutions, in the presence of pristine or organomodified clays using surfactants or not. Particularly, the latter [e.g., dodecylbenzenesulfonic acid (DBSA)] are useful in the case of oxidative polymerization in the presence of organomodified clays, which are hydrophobic and must thus be dispersed in water, hence the necessity of surfactants [17]. For example, it has been demonstrated that DBSA acts as a dopant on top of serving as a surfactant since it is found in the final composition of the clay/PPy nanocomposite. DBSA is deprotonated in water and its anionic form is inserted in the PPy matrix together with anion from the dopant. 


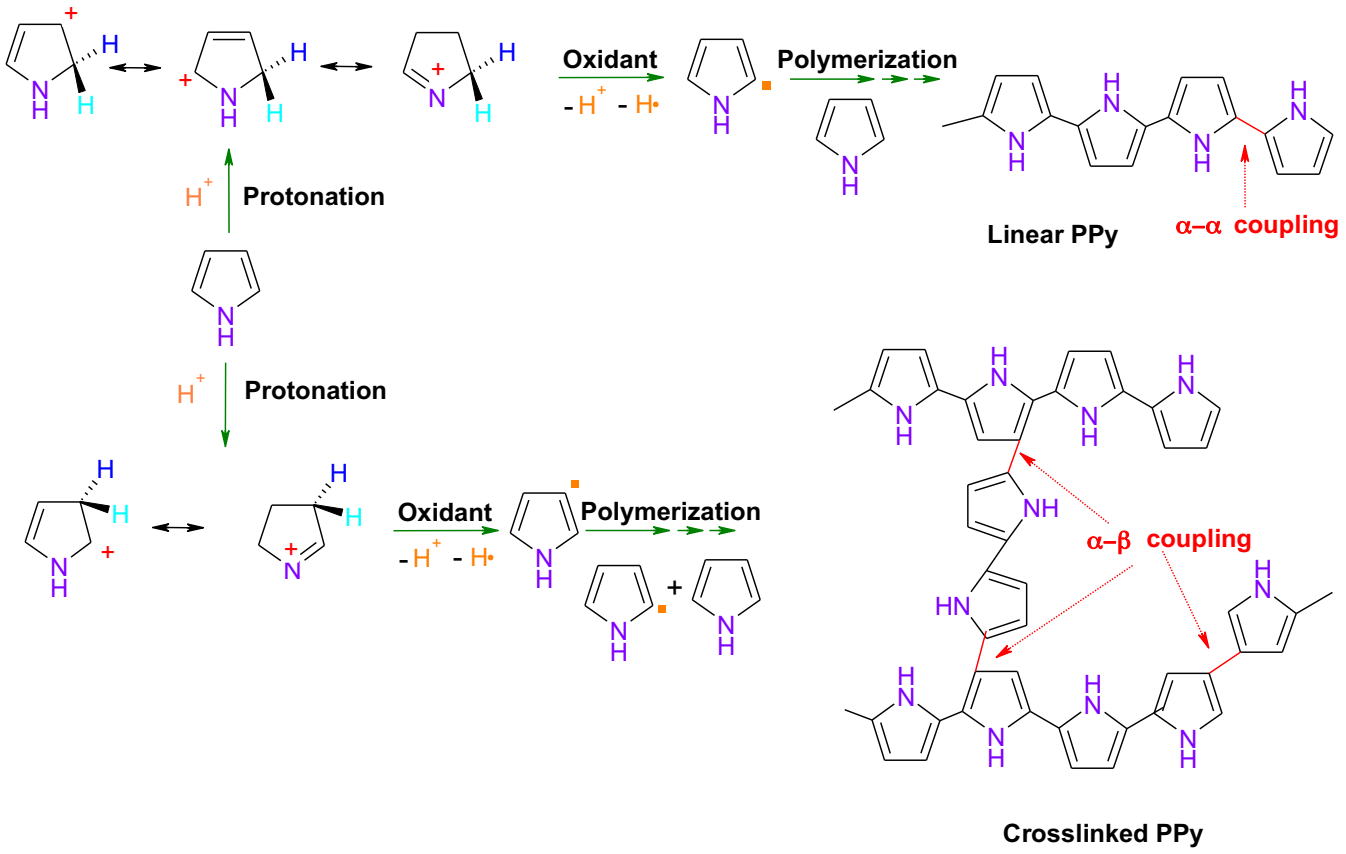

FIGURE 6.5 Protonation and possible polymerization routes of pyrrole by two coupling modes. Adapted with permission of ACS from X-G. Li, A. Li, M-R. Huang, Y. Liao, Y-G. Lu, J. Phys. Chem. C 114 (2010) 19244-19255.

Organomodified clays are commercially available or can be prepared using a range of cationic surfactants such as distearyldimethyl-ammonium chloride [17], hexadecyltrimethyl ammonium bromide $\left(\mathrm{C}_{19} \mathrm{H}_{42} \mathrm{NBr}\right)$ [26] also called cetyl-trimethylammonium bromide, octadecyl-phenyl-dimethylammonium [27], didodecyl-dimethylammonium [27], and 2,2-bis[4-(4aminophenoxy)phenyl]propane (BAPPP) [28]. Polymerization is conducted in the colloidal suspension of clay and proceeds as shown in Fig. 6.3, step (ii), except in the absence of the substrate. Fig. 6.6 schematically shows the preparation of MMT/PPy in water using ammonium persulfate as oxidant (Fig. 6.6A) [29]. The morphology examined by scanning electron microscopy (SEM) (Fig. 6.6B) exhibits deposition of PPy agglomerates on the surface of clay particles, while transmission electron microscopy (TEM) evidenced an intercalated structure of MMT/PPy. Fig. 6.6D schematically illustrates the synthesis of organoclay/polymer nanocomposite with an intercalated cation and the polymer chain.

Kim et al. [30] have described the synthesis of clay/PPy nanocomposites in inverted emulsion, that is, water-in-oil emulsion. Based on the procedure described in Ref. [30], Fig. 6.7 schematically illustrates the prepolymerization 

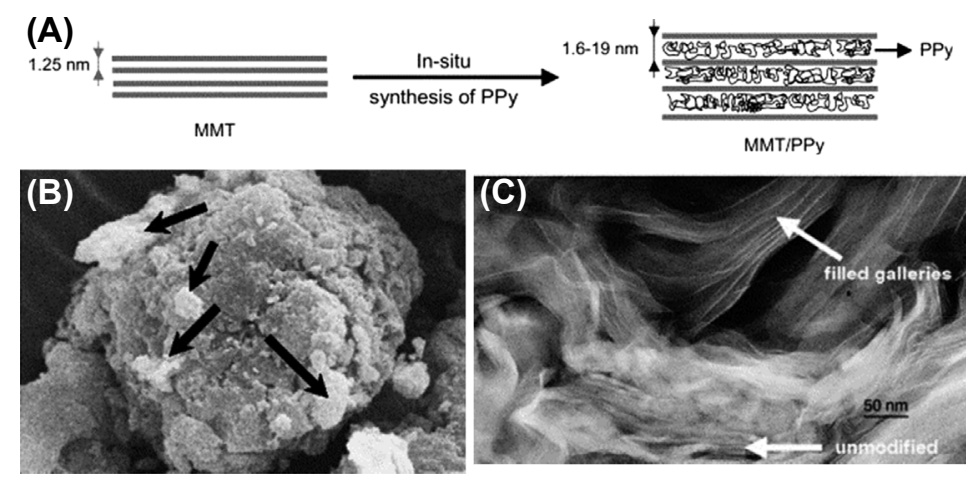

(D)

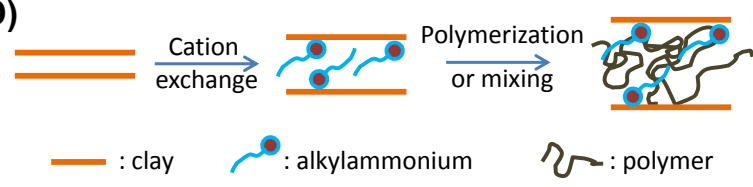

FIGURE 6.6 Synthesis (A) and morphological characterization by scanning electron microscopy (SEM) (B) and transmission electron microscopy (TEM) (C) of montmorillonite/polypyrrole (MMT/PPy) nanocomposite. Arrows in (B) indicate agglomerated particles of PPy at the surface of clay. (D) Shows a scheme of the possible structure of an organoclay/polymer nanocomposite. (A-C) Reproduced with permission of Elsevier from K. Boukerma, J-Y. Piquemal, M.M. Chehimi, M. Mravcáková, M. Omastová, P. Beaunier, Polymer 47 (2006) 569-576.

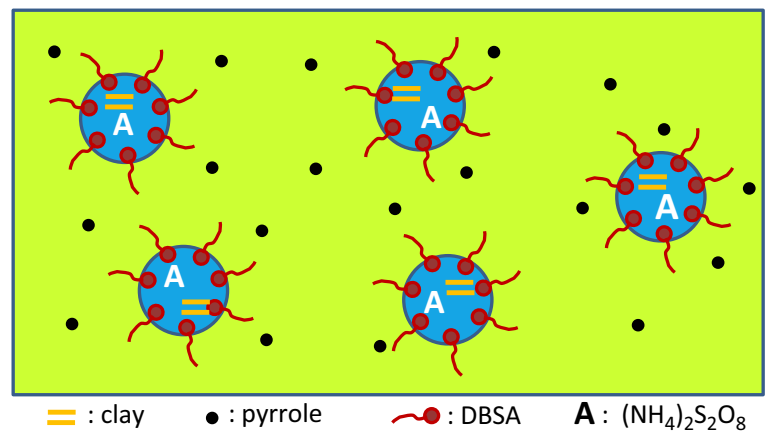

FIGURE 6.7 Prepolymerization system in inverted emulsion for the synthesis of clay/polypyrrole (PPy) nanocomposite. DBSA, dodecylbenzenesulfonic acid.

system in inverted emulsion, after mixing aqueous solution of the oxidant, aqueous suspension of clay, isooctane solution of DBSA, and toluene solution of pyrrole. An intercalated MMT/PPy nanocomposite was obtained with a high DC conductivity of $6 \mathrm{~S} / \mathrm{cm}$ at room temperature.

Clay/PPy nanocomposites were seldom prepared in organic media. This strategy concerned the preparation of nanocomposites by mixing PPy 
(A)

(B)

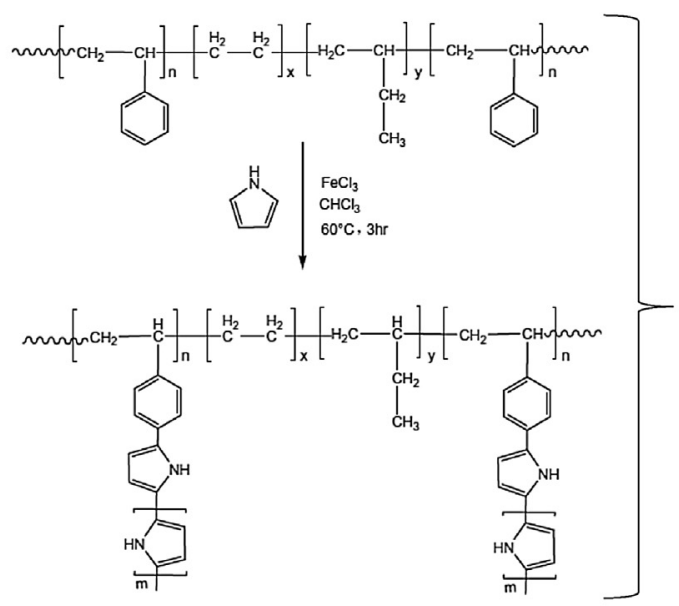

(C)

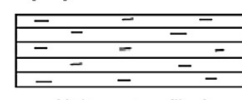

$\mathrm{Na}^{+}$- montmorillonite

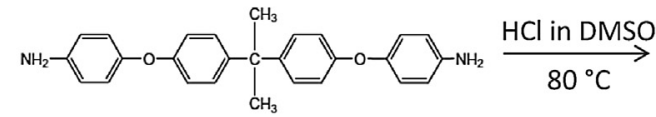

$80^{\circ} \mathrm{C}$

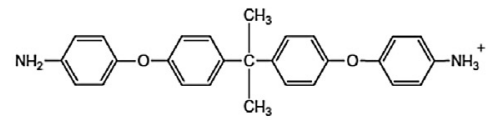

BAPP cation

FIGURE 6.8 (A) Synthesis of SEBS-grafted-polypyrrole (SEBS-g-PPy) block copolymers. (B) Cationization of 2,2-bis[4-(4-aminophenoxy)phenyl]propane (BAPP) in dimethyl sulfoxide (DMSO). (C) Preparation of organomontmorillonite (oMMT) and mixing with SEBS-g-PPy. Adapted with permission of Elsevier from M. Zahra, S. Zulfiqar, C.T. Yavuz, H-S. Kweon, M.I. Sarwar, Compos. Sci. Technol. 100 (2014) 44-52.

block copolymers and organoclays [28,31]. Fig. 6.8 presents the strategy of making highly exfoliated organomontmorillonite (oMMT)/PPy-based nanocomposite in three main steps [28]. Pyrrole is polymerized in the presence of polystyrene- $b$-poly(ethylene-co-butylene)-b-polystyrene (styrene ethylene butylene styrene, SEBS) block copolymer in chloroform to provide SEBS-grafted-polypyrrole (SEBS- $g$-PPy) (step (A)), BAPPP is cationized in dimethyl sulfoxide (step (B)) and exchanged with $\mathrm{Na}^{+}$from MMT (step (C)), and finally, BAPPP cation-exchanged MMT is mixed with SEBS- $g$-PPy to provide a highly exfoliated nanocomposite (second reaction in step (C)). Addition of oMMT up to $3 \mathrm{wt} \%$ improved remarkably well the toughness and tensile modulus of the SEBS- $g$-PPy. The organoclay imparted substantial thermal stability as the thermal decomposition temperature was 
found to be in the $435-448^{\circ} \mathrm{C}$ range, at a higher temperature than the unfilled matrix. Although electrical conductivity was low, it increased upon addition of oMMT until reaching $7 \mathrm{wt} \%$ (from $2 \times 10^{-14}$ to $3 \times 10^{-14} \mathrm{~S} / \mathrm{cm}$ ).

\subsubsection{Photopolymerization}

As introduced earlier, photopolymerization of pyrrole with the incorporation of Group 1B metal particles is interesting for the following reasons: it is conducted in one pot using metal salts as photosensitizers and is very efficient because of the tremendous time saving particularly in the case of PPy/silver nanocomposites.

A proposed mechanism of photopolymerization of pyrrole is depicted in Fig. 6.9. Under UV light, nitrates are decomposed to give the hydroxyl radical ${ }^{\circ} \mathrm{OH}[32]$, which initiates the oxidative polymerization of pyrrole. The resulting oligomers have lower oxidation potential so that they in turn can be oxidized by $\mathrm{Ag}^{+}$yielding AgNPs. Nitrates dope the PPy chains and AgNPs are incorporated in the PPy network.
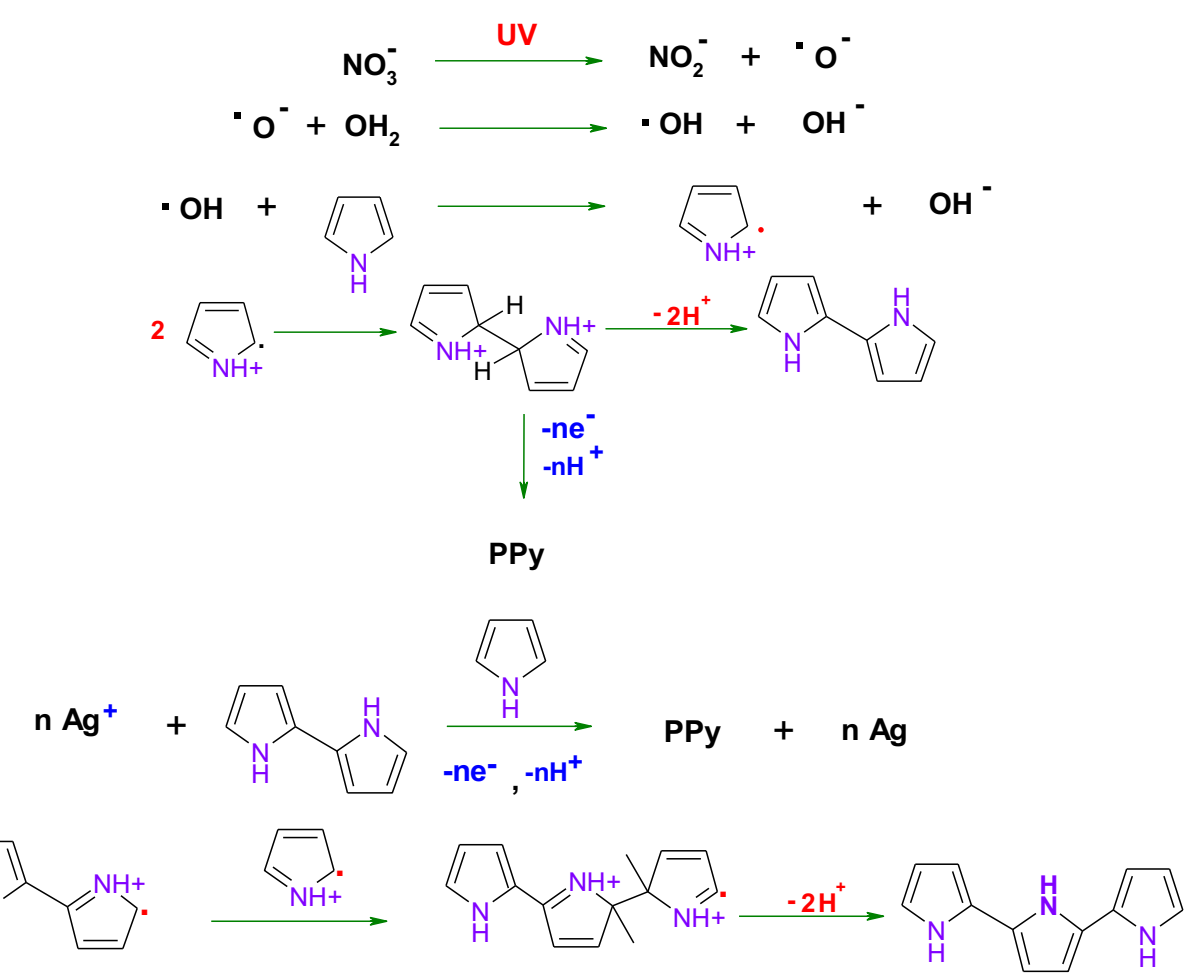

FIGURE 6.9 Mechanism of photopolymerization of pyrrole in the presence of a silver nitrate photosensitizer. 
Similarly, for gold the proposed reaction is given in the presence or absence of surfactant [here sodium dodecylsulfate, (SDS)] [18]:

$$
\begin{aligned}
3 \mathrm{Py}+ & 6 \mathrm{AuCl}_{4}^{-}+\mathrm{h} v \rightarrow[\mathrm{Py}-\mathrm{Py}-\mathrm{Py}]^{+} \mathrm{AuCl}_{4}^{-}+3 \mathrm{HAuCl}_{4}+2 \mathrm{Au}^{0}+8 \mathrm{HCl} \\
3 \mathrm{Py} & +4 \mathrm{AuCl}_{3}+\mathrm{NaDS}+\mathrm{h} v \rightarrow[\mathrm{Py}-\mathrm{Py}-\mathrm{Py}]^{+} \mathrm{DS}^{-}+\mathrm{HAuCl}_{4}+\mathrm{NaCl} \\
& +3 \mathrm{Au}^{0}+7 \mathrm{HCl}
\end{aligned}
$$

The process makes pure PPyAg or PPyAu binary nanocomposites [18] in water or nanocomposite films on various substrates such as woven cotton textile [33] and polyethylene terephthalate plastic sheets [19].

Unfortunately, despite its interest, photopolymerization of pyrrole has rarely been conducted in the presence of clay. This could be ascribed to the excessive price of gold and silver salts. We shall summarize next two case studies of clay/PPyAg systems.

The first example was reported by Jlassi et al. [13] who silanized MMT with $\mathrm{N}$-(3-trimethoxysilypropyl)pyrrole prior to photopolymerization of pyrrole (Fig. 6.10). Silanization was left to proceed for $72 \mathrm{~h}$ because silanes with large groups react slowly with material surfaces. Interestingly, a pyrrole-functionalized silane was used to initiate photopolymerization at the pyrrolyl pending groups tethered to clay. Photopolymerization was conducted for $3 \mathrm{~h}$, which is 16 times shorter compared to the same polymerization in the absence of UV light.

The yield is very good as can be noticed in Fig. 6.10 (right-hand side). The ternary nanocomposite is exfoliated in the case of organoclay (prepared with silane), whereas the reference nanocomposite using Na-MMT has a persisting intercalated structure. The end material was found to be an excellent catalyst of the reduction of methylene blue (MB) taken as a model molecule. Discoloration of the MB solution occurs immediately upon addition of oMMT/PPyAg catalyst powder.

In a similar procedure, ternary attapulgite/PPyAg (ATP/PPyAg) nanocomposite was prepared by photopolymerization of pyrrole [14]. The general procedure is illustrated in Fig. 6.11 (upper panel). TEM permitted the inspection of the deposition of PPyAg all along the clay fibers. AgNPs have a particle size in the $33-40 \mathrm{~nm}$ range and the conductivity of the nanocomposites is in the $0.12-0.44 \mathrm{~S} / \mathrm{cm}$ range depending on the initial clay/pyrrole mass ratio. The ATP/PPyAg was compounded with poly(butylene succinate) (PBS), a biodegradable polymer, and the final PBS-based composite material was evaluated in antibacterial application against Escherichia coli and Staphylococcus aureus. Fig. 6.11 (lower panel, left) 


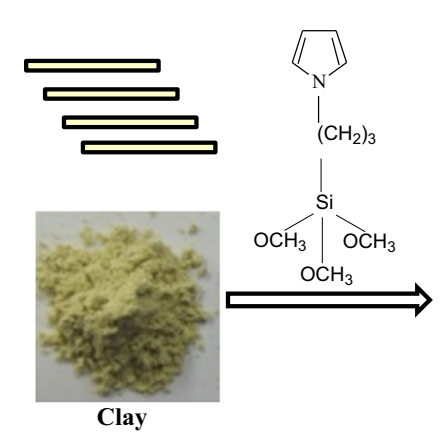

(A)

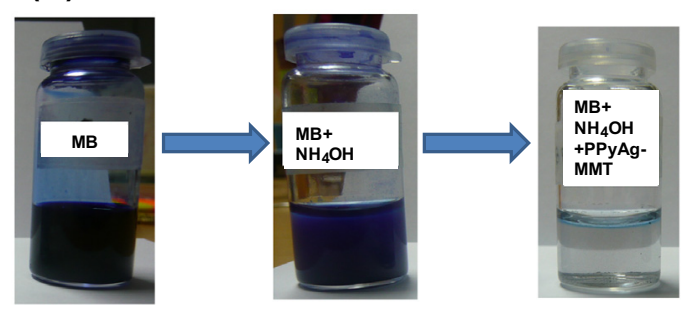

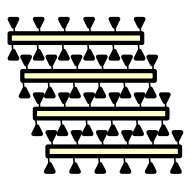
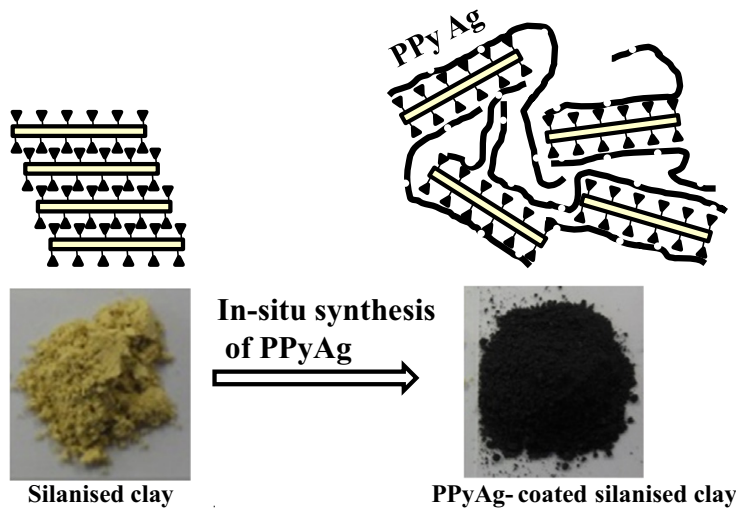

PPyAg-coated silanised clay

(B)

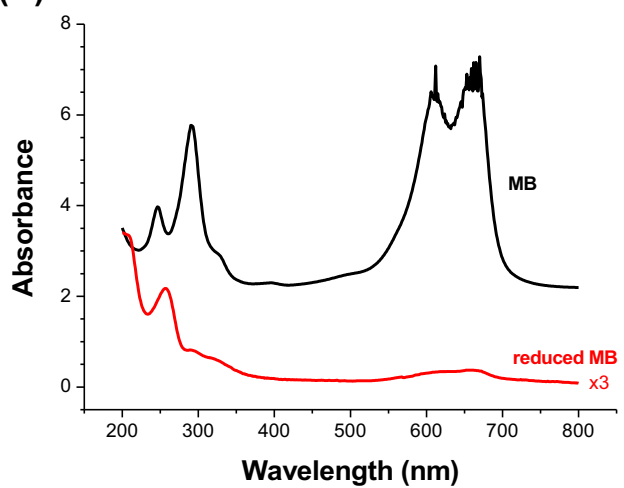

FIGURE 6.10 Upper panel: Protocol of preparation of silanized MMT/PPyAg ternary nanocomposite by photopolymerization. Lower panel: Reduction of methylene blue (MB) by the organoclay/PPyAg. (A) Digital photographs showing the interaction of MB with the reducing solution in the absence and presence of organoclay/PPyAg. (B) Spectra of MB and its reduced form. Reproduced with permission of Elsevier from K. Jlassi, A. Singh, D.K. Aswal, R. Losno, M. Benna-Zayani, M.M. Chehimi, Colloids Surf. A 439 (2013) 193-199.

shows many more E. coli colonies than in the Petri dish containing PBS filled with ATP/PPyAg.

\subsubsection{Synthesis Conditions and Figures of Merit of Selected Clay/Polypyrrole Systems}

Table 6.1 reports the synthesis conditions and physicochemical characteristics of selected clay/PPy nanocomposites prepared by in-situ electrochemical, chemical, and photochemical polymerization methods. We have also implemented data related to the preparation of clay/PPy by mixing. Other strategies of design of clay/PPy nanocomposites were reviewed by the team of Choi [34] and by Omastová and Mičušík [35]. 


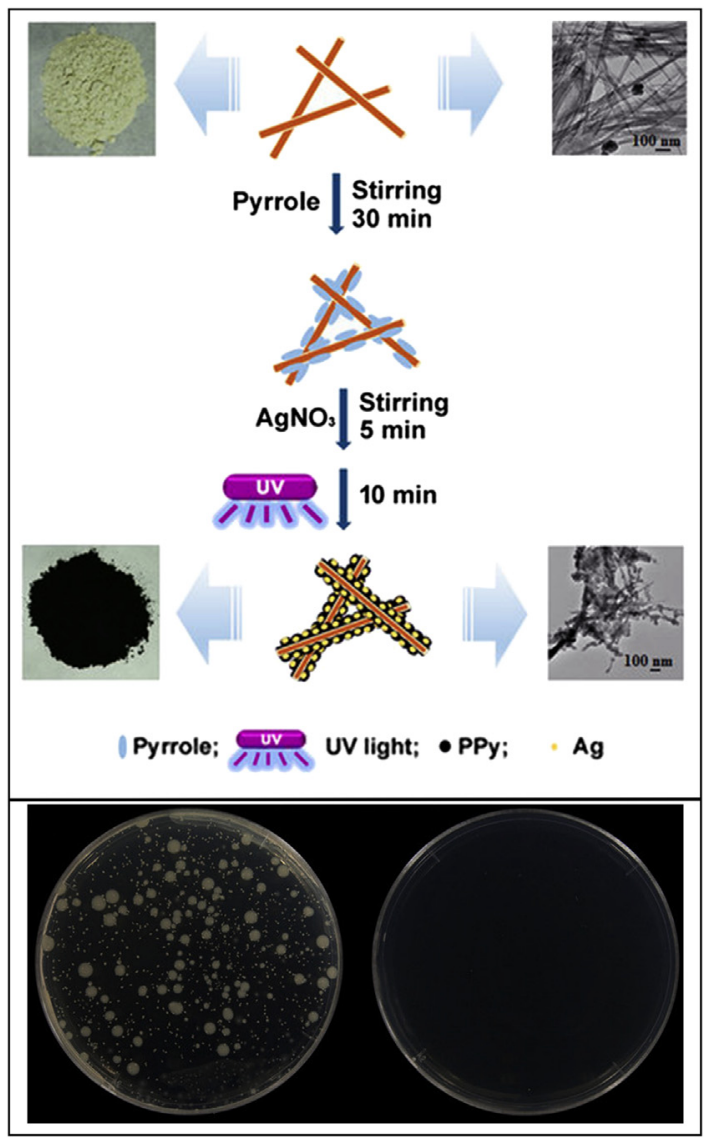

FIGURE 6.11 Upper panel: Pathway to the making of attapulgite/PPyAg nanocomposite. Lower panel: Antibacterial activity against Escherichia coli of poly(butylene succinate) (PBS) (left) and PBS filled with attapulgite/PPyAg (right). Reproduced from L. Zang, J. Qiu, C. Yang, E. Sakai, Sci. Rep. 6 (2016) 20470, http://dx.doi.org/10.1038/ srep20470.

\section{CLAY/POLYANILINE NANOCOMPOSITES}

PANI is one of the most used conducting polymers [37,38] because of its remarkable environmental stability, electrical conductivity (PANI is a p-type conductor) [37], low cost [39], light weight, flexibility, facile synthesis [40], and reactivity imparted by the reactive $\mathrm{NH}$ groups in the polymer chain [41,42]. PANI is used in a wide range of innovative applications such as batteries [43], sensors [44], electronic devices [45], supercapacitors [46], corrosion control protection by PANI-based coatings [47], and thermoelectric power generators [48]. The electrical conductivity of PANI is a very important parameter and it could be tuned by acid/base 
Table 6.1 Summary of Synthesis Conditions, Physicochemical Properties, and Potential Applications of Selected Clay/Polypyrrole Nanocomposites

\begin{tabular}{|c|c|c|c|c|c|c|c|c|}
\hline $\begin{array}{l}\text { Polypyrrole/ } \\
\text { Dopant }\end{array}$ & Clay & $\begin{array}{l}\text { Medium/ } \\
\text { Conditions }\end{array}$ & $\begin{array}{l}\text { Other } \\
\text { Component }\end{array}$ & Structure & $\begin{array}{l}\text { Mass } \\
\text { Loading } \\
\text { (wt\%) }\end{array}$ & $\sigma(S / \mathrm{cm})$ & $\begin{array}{l}\text { Potential } \\
\text { Application }\end{array}$ & References \\
\hline \multicolumn{9}{|c|}{ Electropolymerization } \\
\hline $\mathrm{BF}_{4}^{-}$ & Hectorite & $\begin{array}{l}\text { Process in aqueous } \\
\text { colloidal suspension } \\
\text { or on clay-coated } \\
\text { electrode in } \\
\text { acetonitrile }\end{array}$ & & Intercalated & & & $\begin{array}{l}\text { Electrode } \\
\text { materials or } \\
\text { electrochemical } \\
\text { devices }\end{array}$ & {$[8]$} \\
\hline $\mathrm{ClO}_{4}^{-}$ & Laponite & $\begin{array}{l}\text { Process in aqueous } \\
\text { solution on glassy } \\
\text { carbon coated with } \\
\text { clay/nitrate } \\
\text { reductase/pyrrole } \\
\text { hybrid }\end{array}$ & $\begin{array}{l}\text { Nitrate } \\
\text { reductase }\end{array}$ & & & & $\begin{array}{l}\text { Nitrate } \\
\text { biosensor }\end{array}$ & [23] \\
\hline $\begin{array}{l}\text { Presumably } \\
\text { aspirin }\end{array}$ & Palygorskite & $\begin{array}{l}500 \mathrm{~s} \text { at } 0.8 \mathrm{~V} \text { in } \\
\text { aqueous suspension } \\
\text { of Pal-Asp-PPy } \\
\text { mixture in } \\
\text { poly(butylene } \\
\text { succinate) (PBS) on } \\
\text { indium tin oxide } \\
\text { electrode }\end{array}$ & Aspirin & $\begin{array}{l}\text { Core/shell } \\
\text { fibrillar Pal/PPy }\end{array}$ & & & $\begin{array}{l}\text { Controlled drug } \\
\text { release }\end{array}$ & [16] \\
\hline \multicolumn{9}{|c|}{ Oxidative Polymerization } \\
\hline \multirow[t]{3}{*}{$\mathrm{SO}_{4}$} & $\begin{array}{l}\text { Montmorillonite } \\
\text { (MMT), } \\
\text { Wyoming type }\end{array}$ & $\begin{array}{l}1 \mathrm{~h} \text { polymerization } \\
\text { in MMT suspension, } \\
\text { potassium } \\
\text { persulfate/ } \\
\text { pyrrole }=1 / 2, \mathrm{MMT} / \\
\text { PPy left to decant } 24 \\
\mathrm{~h}\end{array}$ & - & Intercalated & $\begin{array}{l}2.8 \% \\
-21.4 \%\end{array}$ & $\begin{array}{l}\text { Insulating to } \\
10^{-3} \mathrm{~S} / \mathrm{cm}\end{array}$ & Conductive filler & {$[29]$} \\
\hline & $\begin{array}{l}\text { MMT Kunipia } \\
\text { type }\end{array}$ & $\begin{array}{l}\text { Aqueous solution of } \\
\text { DBSA, } \mathrm{FeCl}_{3} \text { oxidant }\end{array}$ & - & & $\begin{array}{l}15 \% \\
\text { (PPy) }\end{array}$ & $\begin{array}{l}9.1 \times 10^{-3} \\
-5.9 \times 10^{-2}\end{array}$ & Conductive filler & [17] \\
\hline & Nanofil 15 & $\begin{array}{l}\text { Aqueous solution of } \\
\text { DBSA and } \mathrm{FeCl}_{3} \\
\text { oxidant }\end{array}$ & & & $\begin{array}{l}15 \% \\
\text { (PPy) }\end{array}$ & $1.1 \pm 0.1$ & Conductive filler & {$[17]$} \\
\hline
\end{tabular}




\begin{tabular}{|c|c|c|c|c|c|c|c|c|}
\hline lodine & $\begin{array}{l}\text { Various naturally } \\
\text { Fe-rich or Fe(III)- } \\
\text { exchanged MMT } \\
\text { and smectites }\end{array}$ & Water/methanol & & Intercalated & $\begin{array}{l}\text { NA but } \\
\text { initial } \\
\text { pyrrole } \\
\text { loading } \\
\text { provided }\end{array}$ & $\begin{array}{l}10^{-9}-10^{-5} \\
\text { for clay/PPy } \\
\text { and } 10^{-5} \\
-10^{-3} \text { for } \\
\text { organoclay/ } \\
\text { PPy }\end{array}$ & $\begin{array}{l}\text { Electrode } \\
\text { materials }\end{array}$ & [27] \\
\hline $\mathrm{Cl}^{-}$ & $\begin{array}{l}\mathrm{Ce}(\mathrm{IV})- \\
\text { exchanged MMT }\end{array}$ & $\begin{array}{l}1 \mathrm{~g} \text { of }[\mathrm{Ce}(\mathrm{IV}) / \mathrm{MMT}] \\
0.05 \mathrm{M} \mathrm{pyrrole} \mathrm{in} \\
0.1 \mathrm{M} \mathrm{HCl}, 48 \mathrm{~h}\end{array}$ & & $\begin{array}{l}\text { Intercalated, } \\
d_{001}=1.83 \mathrm{~nm}\end{array}$ & $\begin{array}{l}\text { Residue } \\
\text { wt of } \\
86 \% \text { at } \\
500^{\circ} \mathrm{C} \text { for } \\
{[\mathrm{Ce}(\mathrm{III}) /} \\
\mathrm{PPy} / \\
\mathrm{MMT}]\end{array}$ & $\begin{array}{l}1.8-4.9 \times \\
10^{-3} \mathrm{~S} / \mathrm{cm}\end{array}$ & $\begin{array}{l}\text { Cathodes in fuel } \\
\text { cells }\end{array}$ & [36] \\
\hline \multicolumn{9}{|c|}{ Photopolymerization } \\
\hline $\mathrm{PPyNO}_{3}$ & $\begin{array}{l}\text { Bentonite } \\
\text { silanized with } \\
\text { TMSPP }\end{array}$ & $\begin{array}{l}\text { Process in water in } \\
\text { the presence of } \\
\text { silanized clay }\end{array}$ & AgNPs & Exfoliated & $\begin{array}{l}19 \% \\
\text { (PPy) and } \\
27 \%(\mathrm{Ag})\end{array}$ & - & $\begin{array}{l}\text { Catalyst of } \\
\text { methylene blue } \\
\text { reduction }\end{array}$ & [13] \\
\hline $\mathrm{PPyNO}_{3}$ & Attapulgite & $\begin{array}{l}\text { Process in water. } \\
\text { ATP dispersed first, } \\
\text { pyrrole added, then } \\
\mathrm{AgNO}_{3}, 10 \mathrm{~min} \\
\text { photopolymerization }\end{array}$ & $\begin{array}{l}\text { AgNPs (33 } \\
-40 \mathrm{~nm})\end{array}$ & - & - & $0.12-0.34$ & $\begin{array}{l}\text { Antibacterial } \\
\text { PBS/attapulgite/ } \\
\text { PPyAg } \\
\text { composite }\end{array}$ & [14] \\
\hline
\end{tabular}


doping/dedoping chemistry $[49,50]$ or by the addition of inorganic fillers [51], among other approaches.

The rationale for making clay/PANI nanocomposite is that the anilinium cation can be intercalated easily in the clay interlayer spacing, in a similar manner to that of ammonium ions.

In the following we will summarize the literature pertaining to the synthesis of clay/PANI by electrochemical and chemical methods and report some interesting applications; note however, that electrochemical methods tend to have lower yields than chemical routes [52]. Moreover, uncommon methods such as enzyme-catalyzed polymerization [53] and photochemically initiated polymerization were also employed [54].

\subsection{Oxidative Electropolymerization}

Electrochemical synthesis of PANI offers many advantages: simplicity of the process, formation of adhering films on the working electrodes, and reversible switching from oxidized to reduced form of PANI. As far as clays are concerned, Chen and Yang [55] intercalated MMT with platinum by insitu reduction of $\mathrm{Pt}\left(\mathrm{NH}_{3}\right)_{4}{ }^{2+}$ using $\mathrm{NaBH}_{4}(\mathrm{Pt} / \mathrm{MMT})$ and further intercalated anilinium ion in acidic solution (Pt/MMT). The intercalated MMTs were coated on platinum electrodes and electropolymerization triggered at $0.8 \mathrm{~V}$ (vs. $\mathrm{Ag} / \mathrm{AgCl}$ ). The authors found much higher oxidation peak current for platinum electrodes coated with PANI $/ \mathrm{Pt} / \mathrm{C}_{6} \mathrm{H}_{5} \mathrm{NH}_{3}{ }^{+}$MMT compared to PANI/MMT and hybrid coatings without Pt inside the clay (Fig. 6.12). Without any MMT, a much lower oxidation peak area was recorded.

In another study, electropolymerization of anilinium-MMT dispersions by potentiostatic electrolysis resulted in the deposition of an adherent film of MMT/PANI nanocomposite on the electrode surface [56]. The authors optimized the making of adhering film by testing the electrochemical method, aniline concentration, and acid employed. The MMT/PANI films did not form and adhere to the electrode in the case of potentiodynamic cycling (in the $-200-900 \mathrm{mV}$ range) and use of high speed. A constant potential of $700 \mathrm{mV}$ (vs. saturated calomel), stirring at $80 \mathrm{rpm}$, and an aniline concentration of $\geq 0.1 \mathrm{M}$ and $\mathrm{pH} 1-2$ in $\mathrm{H}_{2} \mathrm{SO}_{4}, \mathrm{HClO}_{4}$, or oxalic acid were the optimized conditions. Intercalation was noted by X-ray diffraction (XRD) given the increase of the MMT $d_{001}$ spacing from $1.0 \mathrm{~nm}$ to $1.28,1.26$, and $1.25 \mathrm{~nm}$ for anilinium-MMT, MMT/PANI oxidized form, and MMT/PANI reduced form, respectively. The authors ascribed the sharp diffraction peak of anilinium-MMT to a better crystallinity or clay-layer stacking order. In-situ electrochemical determination 


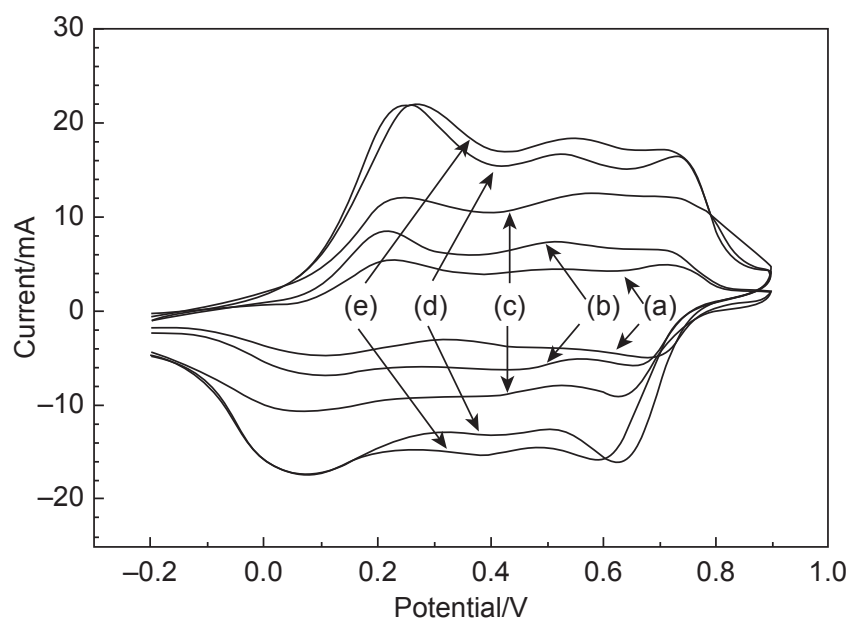

FIGURE 6.12 Cyclic voltammogram of (A) polyaniline (PANI), (B) PANI $/ \mathrm{C}_{6} \mathrm{H}_{5} \mathrm{NH}_{3}+-$ MMT, (C) PANI/montmorillonite (MMT), (D) PANI/Pt/ ${ }_{6} \mathrm{H}_{5} \mathrm{NH}_{3}{ }^{+}-$MMT, and (E) PANI/Pt/MMT. Reproduced with permission of Elsevier from K.H. Chen, S.M. Yang, Synth. Met. 135-136 (2003) 151-152.

of film resistance versus potential indicated highly conductive films; MMT/ PANI is about twofold more resistant than pure PANI despite an important loading of clay $(90 \mathrm{wt} \%)$.

\subsection{Oxidative Chemical Polymerization}

Oxidative chemical synthesis of PANI requires three reactants: aniline, an acidic medium (aqueous or organic), and an oxidant. The more common acids are essentially hydrochloric acid $(\mathrm{HCl})$ and sulfuric acid $\left(\mathrm{H}_{2} \mathrm{SO}_{4}\right)$. Ammonium persulfate $\left[\left(\mathrm{NH}_{4}\right)_{2} \mathrm{~S}_{2} \mathrm{O}_{8}\right]$, potassium dichromate $\left(\mathrm{K}_{2} \mathrm{Cr}_{2} \mathrm{O}_{7}\right)$, cerium sulfate $\left[\mathrm{Ce}\left(\mathrm{SO}_{4}\right)_{2}\right]$, sodium vanadate $\left(\mathrm{NaVO}_{3}\right)$, potassium ferricyanide $\left(\mathrm{K}_{3}\left[\mathrm{Fe}(\mathrm{CN})_{6}\right]\right)$, potassium iodate $\left(\mathrm{KIO}_{3}\right)$, and hydrogen peroxide $\left(\mathrm{H}_{2} \mathrm{O}_{2}\right)$ are recommended as oxidants [57].

The mechanism of oxidative polymerization of aniline through electrochemical and chemical synthesis usually involves (Fig. 6.13) [58]:

1. Oxidation of nitrogen atom of monomer followed by oxidation of end nitrogen atom of the oligomers and polymers;

2. Addition of monomer in the "nitrogen-carbon" fashion as a result of chain reaction (electrophilic substitution of a proton in the aromatic ring of the monomer by an oxidized polymer fragment).

Most probably in the induction period, aniline radical cations are formed; this process is followed by their recombination (according to the electrophilic 


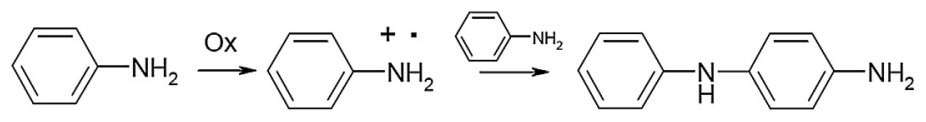
Induction period

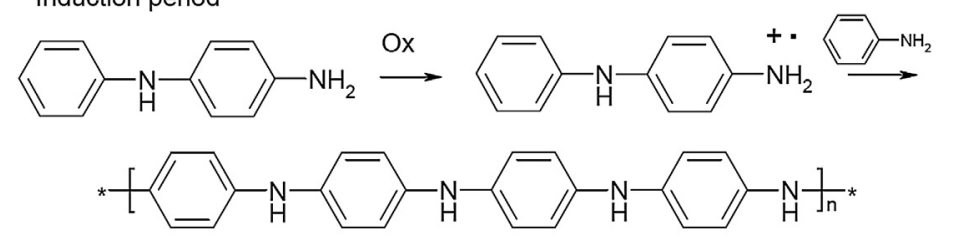

Chain propagation step

FIGURE 6.13 Mechanism of aniline oxidative polymerization. Reproduced from I.Y. Sapurina, M.A. Shishov, Oxidative polymerization of aniline: molecular synthesis of polyaniline and the formation of supramolecular structures, in: A. De Souza Gomes (Ed.), New Polymers for Special Applications, InTech, 2012, http://dx.doi.org/10.5772/48758. Available from: http://www.intechopen.com/books/new-polymersfor-special-applications/oxidative-polymerization-of-aniline-molecular-synthesis-of-polyaniline-and-theformation-of-supramol.

substitution mechanism) to afford a dimer, namely, $N$-phenylphenylene-1,4diamine ( $p$-semidine). The subsequent propagation step is assumed to be similar to the electrophilic substitution process where the oxidized terminal amino group of oligomer (polymer) attacks the paraposition in the monomer.

PANI can exist in several oxidation states ranging from the completely reduced base state to the completely oxidized state (leucoemeraldine, emeraldine, and pernigraniline forms) that differ in chemical and physical properties. For example, PANI conductivity depends directly on the extent of oxidation (variation in the number of electrons) and the degree of protonation (variation in the number of protons, see Fig. 6.14 [58]).

The most studied form of the polymer is emeraldine, obtained with a $1 \mathrm{~mol}$ aqueous hydrochloric acid solution and ammonium persulfate as oxidant with an oxidant/aniline molar ratio $\leq 1.15$ to obtain high conductivity and yield [59]. The reaction is conducted under 0 and $2^{\circ} \mathrm{C}$ for a duration between 1 and $2 \mathrm{~h}$ to limit secondary reactions.

Clay induces drastic improvement in the thermal and conducting properties of clay/PANI nanocomposites. This is attributed to the presence of PANI in the nanoscaled clay interlayer spaces in a high aspect ratio where the clay layers are acting as barriers protecting PANI from degradation. In the case of organoclays, PANI undergoes more favorable molecular interactions and eventually grafting. Particularly, because of the reactivity of PANI through its $\mathrm{NH}$ groups, Jlassi et al. [12,60] have demonstrated that diphenylamine-grafted clay via interface diazonium reactions provide a 

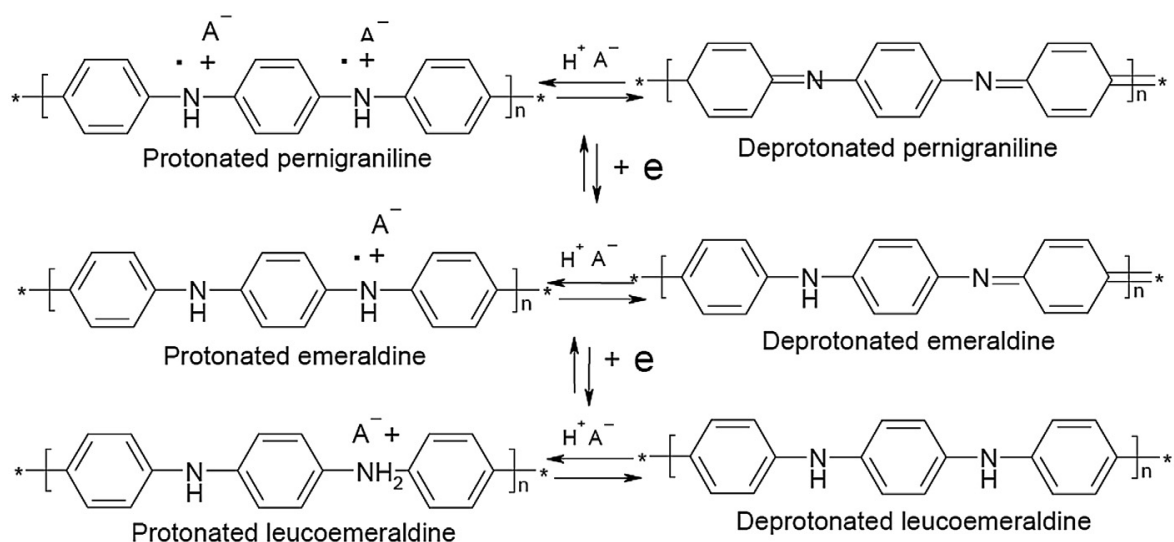

FIGURE 6.14 Polyaniline forms. Reproduced from Reproduced from I.Y. Sapurina, M.A. Shishov, Oxidative polymerization of aniline: molecular synthesis of polyaniline and the formation of Supramolecular structures, in: A. De Souza Gomes (Ed.), New Polymers for Special Applications, InTech, 2012, http://dx.doi.org/10. 5772/48758. Available from: http://www.intechopen.com/books/new-polymers-for-special-applications/oxidative-polymerization-of-aniline-molecular-synthesis-ofpolyaniline-and-the-formation-of-supramol.

macromonomer that is copolymerized with aniline. This process results in the formation of exfoliated, conductive clay/PANI nanocomposites potentially useful as conductive fillers for epoxy. Mixing diazoniummodified bentonite/PANI filler with epoxy and diaminodiphenylsulfone (DDS) hardener results in a unique interfacial chemistry (see Section 4.3).

The most widely used methods to prepare PANI/clay nanocomposites are based on solution intercalation polymerization techniques [61]. Clay materials cannot induce spontaneously the polymerization of aniline, therefore the use of oxidant is crucial. Ammonium persulfate is the most popular oxidant used for aniline polymerization since it is suitable for mass production of PANI; some studies have investigated the use of other oxidants such as iron(III) chloride/ozone [62] or $\mathrm{Fe}^{3+}$ present in clay as interlayer cation $[63,64]$. Work of the team of Srasra $[64,65]$ has shown that $\mathrm{Fe}^{3+}$ ions present in the octahedral structure of MMT act as efficient initiator for aniline polymerization by a simple grinding activation of clay, that is, by mechanochemical processing. The authors obtained a branched fibrous morphology of PANI caused by the templating effect of the clay structure and the oxidant role of the octahedral $\mathrm{Fe}^{3+}$ cations.

\subsection{Applications of Clay/Polyaniline Systems}

Table 6.2 reports, for selected systems, the synthesis conditions, physicochemical features, and potential applications. Eye-catching case studies will be reported later. 


\begin{tabular}{|c|c|c|c|c|c|c|c|c|}
\hline PANI/Dopant & Clay & $\begin{array}{l}\text { Coupling } \\
\text { Agent }\end{array}$ & $\begin{array}{l}\text { Other } \\
\text { Component }\end{array}$ & Structure & Mass Loading & $\begin{array}{l}\text { Potential } \\
\text { Application }\end{array}$ & $\begin{array}{l}\text { Conductivity } \\
\text { (S/cm) }\end{array}$ & References \\
\hline \multicolumn{9}{|c|}{ Oxidative Polymerization } \\
\hline $\begin{array}{l}\mathrm{Fe}^{3+} \text { cations } \\
\text { localized at clay } \\
\text { octahedral layers } \\
\text { and atmospheric } \\
\text { oxygen act as } \\
\text { oxidant } \\
\text { Anilinium chloride } \\
\text { (AnCl) }\end{array}$ & $\begin{array}{l}\text { Montmorillonite } \\
\text { (MMT) }\end{array}$ & - & $\begin{array}{l}\mathrm{O}_{2} \\
\text { Oxidation of } \\
\text { MMT } \\
\text { octahedral } \\
\mathrm{Fe}^{2+}>\mathrm{Fe}^{3+}\end{array}$ & Exfoliated & $\begin{array}{l}\text { AnCl/CEC = 3, } \\
3.5,5,10,30 \\
\text { MMT ground } \\
\text { using a } \\
\text { Retsch mortar } \\
\text { grinder for } \\
30 \text { min } \\
\text { Mechano- } \\
\text { chemical } \\
\text { grinding } \\
\text { MMT + AnCl/ } \\
2 \mathrm{~h} \\
14 \text { days' } \\
\text { aging/room } \\
\text { temperature }\end{array}$ & Solar cell & $1.66 \times 10^{-3}$ & [65] \\
\hline $\begin{array}{l}\text { APS } \\
\text { Sulfuric acid }\end{array}$ & Palygorskite & - & & $\begin{array}{l}\text { Same } \\
\text { as } \\
\text { pristine }\end{array}$ & $\begin{array}{l}\text { Palygorskite/ } \\
\text { aniline/sulfuric } \\
\text { acid/APS } \\
7 \mathrm{~g} / 5.58 \mathrm{~g} / \\
200 \mathrm{~mL}, 2 \mathrm{M} / \\
0.4 \mathrm{M} \\
\quad \text { Vigorous } \\
\text { stirring for } \\
6 \mathrm{~h} / \text { room } \\
\text { tempersture } \\
\text { Drying at } \\
60^{\circ} \mathrm{C} / 24 \mathrm{~h}\end{array}$ & $\begin{array}{l}\text { Electrical } \\
\text { engineering } \\
\text { applications }\end{array}$ & $10^{-3}$ & [63] \\
\hline
\end{tabular}




\begin{tabular}{|c|c|c|c|c|c|c|c|c|}
\hline $\begin{array}{l}\text { APS } \\
\text { Hydrochloric acid }\end{array}$ & Attapulgite & - & $\begin{array}{l}\text { Polyvinyl } \\
\text { alcohol (PVA) }\end{array}$ & NA & $\begin{array}{l}\text { Clay/aniline/ } \\
\text { HCl/APS } \\
\text { NA/7.3 mL/ } \\
100 \mathrm{~mL} \\
-2.0 \mathrm{mM} / 0.4 \mathrm{M} \\
\text { Vigorous } \\
\text { stirring, }-4 \mathrm{~h} / \\
0^{\circ} \mathrm{C}\end{array}$ & $\begin{array}{l}\text { Electrochemical } \\
\text { removal of } \mathrm{Pb}(\mathrm{II}) \\
\text { from aqueous } \\
\text { solutions }\end{array}$ & NA & [66] \\
\hline $\begin{array}{l}\text { APS } \\
\text { Nitric acid }\end{array}$ & Bentonite & DPA & - & Exfoliated & $\begin{array}{l}\text { DPA/ } \\
\text { CEC = } 0.6, \\
1.3,2 \\
\text { B-DPA/ } \\
\text { aniline/APS } \\
8 \mathrm{mg} / \\
154.5 \mathrm{mg} / \\
91.3 \mathrm{mg} \\
4 \mathrm{~h} / \text { ice bath }\end{array}$ & $\begin{array}{l}\text { Epoxy } \\
\text { mechanical and } \\
\text { dielectric } \\
\text { improvement }\end{array}$ & $2.4 \times 10^{-3}$ & {$[12,60]$} \\
\hline $\begin{array}{l}\text { APS } \\
\text { Hydrochloric acid }\end{array}$ & Cloisite 30B & $\begin{array}{l}\text { Methyl- } \\
\text { tallow-bis-2- } \\
\text { hydroxyethyl }\end{array}$ & $\begin{array}{l}\text { Epoxy } \\
N \text {-methyl } \\
\text { pyrrolidone }\end{array}$ & Exfoliated & $\begin{array}{l}\text { Clay/aniline = } \\
3 \text { wt } \% \\
\text { Molar ratio of } \\
\text { APS/ } \\
\text { aniline }=1.15\end{array}$ & $\begin{array}{l}\text { Corrosion } \\
\text { protection by } \\
\text { epoxy coatings }\end{array}$ & NA & [67] \\
\hline
\end{tabular}




\section{- CASE STUDY 1: CONDUCTIVE, EXFOLIATED CLAY/POLYANILINE NANOCOMPOSITE FILLER}

Jlassi et al. [60] described the preparation of ternary epoxy composites using clay/PANI hybrids as nanofillers. The latter were prepared by oxidative polymerization of aniline in the presence of pristine or 4-diphenylamino-diazonium-exchanged clay-modified bentonite (B and B-DPA, respectively). The B-DPA/PANI was evaluated as filler for a diglycidyl ether of bisphenol-A epoxy matrix.

The mechanism of reaction of diphenylamine diazonium cation and clay followed by in-situ oxidative polymerization of aniline is displayed in Fig. 6.15.

The exfoliated clay has NH groups from either DPA or PANI, which react with epoxy groups via ring opening, therefore ensuring covalent attachment of the resin to the clay sheets (via PANI and DPA). Similarly, the DDS hardener has two amino groups that react with epoxy by ring opening leading to cross-linking of the resin (Fig. 6.16).

First, the diazonium cation-exchanged bentonite imparts high interlamellar spacing in the nanocomposites and a high exfoliation is reached for an initial concentration of the diazonium salt equal to two times the cation exchange capacity (Fig. 6.17B). Moreover, the diazonium modification of clay induces five orders of magnitude higher conductivity compared to the pristine clay/PANI nanocomposite. As schematically shown in Fig. 6.17A, diphenylamine groups impart excellent wetting of the clay lamellae by PANI. After reaction with the epoxy resin, synergetic effects of DPA and PANI on the mechanical and dielectric properties of the epoxy matrix were noted. The fracture toughness increased by $20 \%-30 \%$ in the case of the B/PANI filler, while the addition of B-DPA/PANI increased the fracture toughness by $210 \%-220 \%$ (Fig. 6.17D). This was assigned to DPA groups grafted to bentonite lamellae, which favored effective stress transfer medium. SEM permitted the visualization of completely different fracture surfaces depending on the filler nature. B-DPA/PANI induces a very particular fibrillar structure indicating ductile failure mode, whereas the B/PANI induces a smooth fracture surface, which accounts for brittle failure mode (Fig. 6.17C). It is thus clear that diazonium salts contribute remarkably well to achieve very strong adhesion between the nanofiller and the epoxy matrix. 
(A)
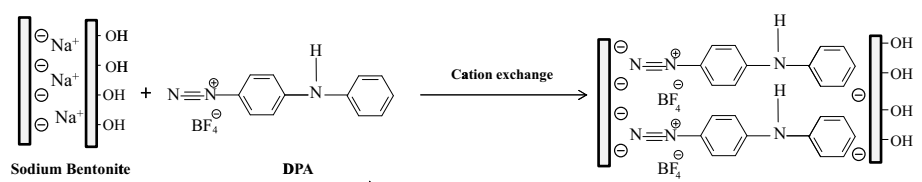

Sodium Bentonit

(A)
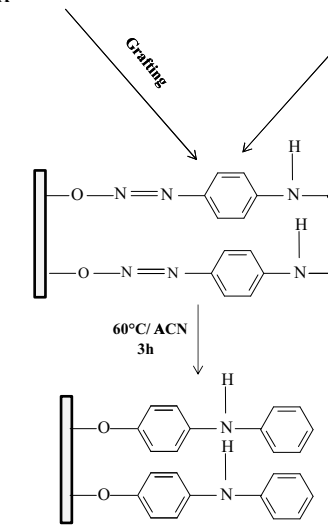

(c)

(a)

\section{(b)}

(B)

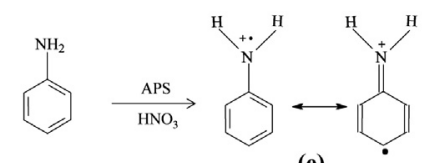

(e)

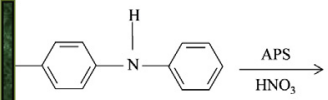

(a) or (b) or (c)

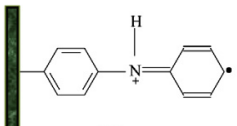

(d)

(d) + (e)

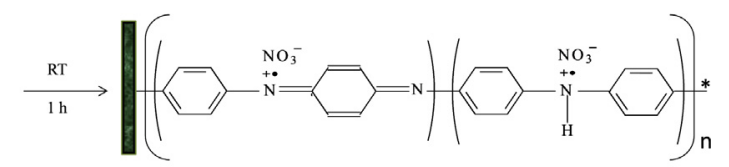

(f)

FIGURE 6.15 Chemical route for intercalating bentonite by diazonium cation exchange reaction and in-situ polymerization ( $A$, upper panel). Simplified mechanism of interfacial oxidative polymerization of aniline (B, lower panel). ACN, acetonitrile; APS, ammonium persulfate; DPA, 4-diphenylamino-diazonium. Reproduced with permission of RSC from K. Jlassi, A. Mekki, M. Benna-Zayani, A. Singh, D.K. Aswal, M.M. Chehimi, RSC Adv. 4 (2014) 65213-65222.

The dielectric properties were also found to be affected by the use or not of the diazonium compounds to make a nanocomposite filler. The filled epoxy was found to be nonconductive in the case of B/PANI in contrast to filling with $0.5 \mathrm{wt} \%$ B-DPA/PANI. 


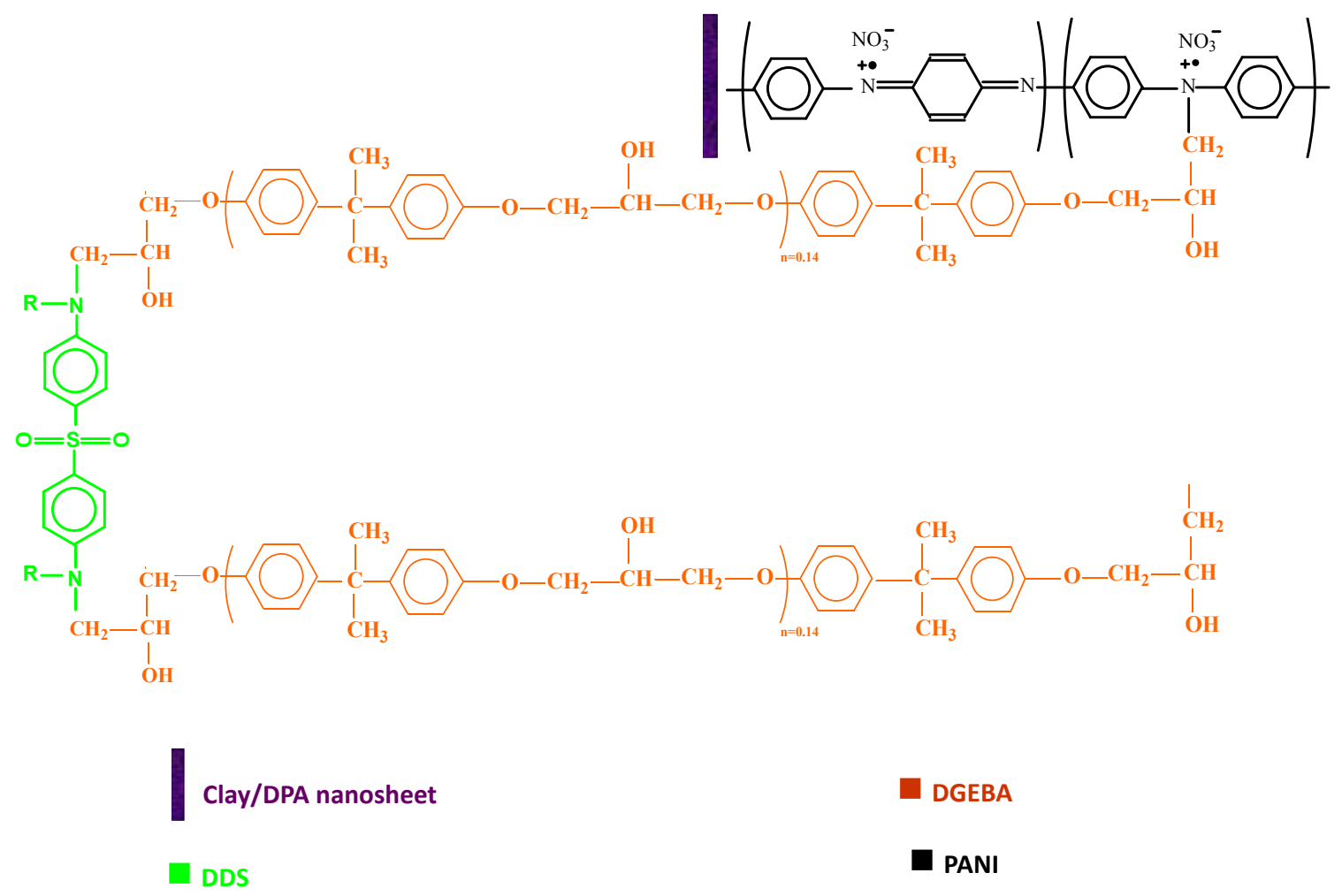

FIGURE 6.16 Molecular view of the ternary 4-diphenylamino-diazonium-exchanged clay-modified bentonite/polyaniline (B-DPA/PANI) reaction with the diglycidyl ether of bisphenol-A/diaminodiphenylsulfone (DGEBA/DDS) system. Reproduced with permission of ACS from K. Jlassi, S. Chandran, M. A Poothanari, M. Benna-Zayani, S. Thomas, M.M. Chehimi, Langmuir 32 (2016) 3514-3524.

(A)

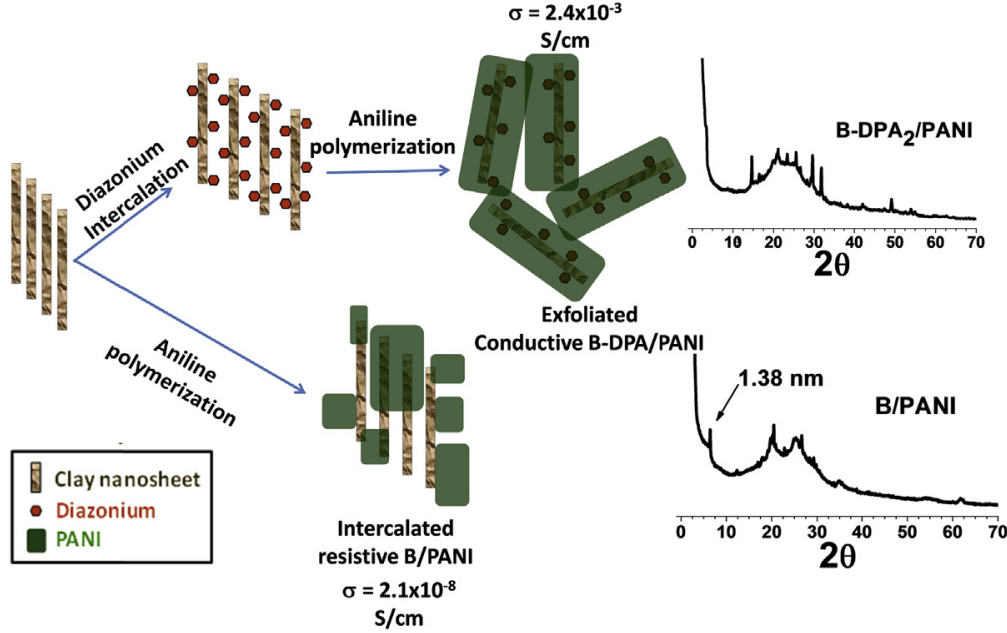

(C)
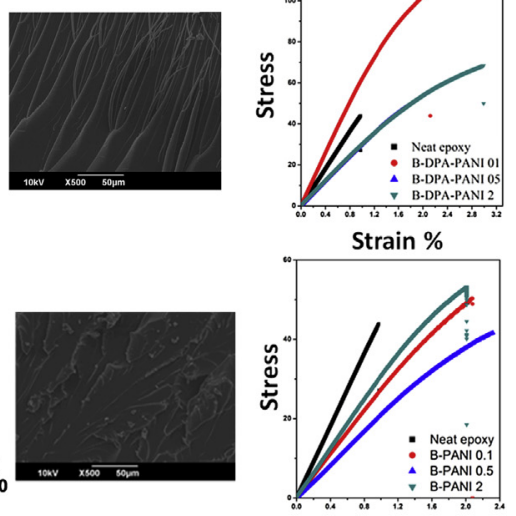

Strain \%

FIGURE 6.17 Upper row: Oxidative in-situ polymerization of polyaniline in the presence of diazonium salt-modified bentonite (B-DPA). Lower row: Oxidative in-situ polymerization of polyaniline in the presence of pure bentonite B. (A) Synthesis of hybrid fillers with (upper) and without (lower) diazonium; (B) small angle X-ray scattering patterns; (C) scanning electron microscopy (SEM) image of fracture surface of epoxy matrix filled with B-DPA/PANI (upper row) and B/PANI (lower row); (D) fracture toughness of epoxy reinforced with B-DPA/PANI and B/PANI. (B) Reproduced with permission of RSC from K. Jlassi, A. Mekki, M. Benna-Zayani, A. Singh, D.K. Aswal, M.M. Chehimi, RSC Adv. 4 (2014) 65213-65222 and other images (A, C, and D) reproduced with permission of ACS from K. Jlassi, S. Chandran, M. A Poothanari, M. Benna-Zayani, S. Thomas, M.M. Chehimi, Langmuir 32 (2016) 3514-3524. 


\section{- CASE STUDY 2: OMMT/PANI FILMS FOR THE SIMULTANEOUS DETECTION OF METAL IONS}

De Barros et al. [15] described the preparation of 20 monolayer LangmuirBlodgett (LB) films on indium tin oxide (ITO) from mixtures of camphorsulfonic acid-doped PANI solution (in an $m$-cresol/chloroform mixture) and oMMT dispersion (in a butanol-benzene mixture). The LB films were employed to trap $\mathrm{Cd}^{2+}, \mathrm{Pb}^{2+}$, and $\mathrm{Cu}^{2+}$ metal ions that were reduced electrochemically at the surface of the nanocomposite-coated ITO and then stripped in the anodic wave.

The authors demonstrated with XRD that PANI-emeraldine salt (ES)/ oMMT LB films exhibit an unmodified clay structure. In contrast, the polaronic state of PANI-ES is affected in the sense that semiconducting polymers and clay minerals may be combined for enhancing the electrical properties of nanostructures, which is beneficial for sensing. Surface plasmon resonance studies indicated hybrid films to be much better ordered than those of the neat PANI.

As far as the electroanalytical application of the LB films is concerned, the square wave anodic stripping (SWAS) voltammetry approach is schematically depicted in Fig. 6.18 (upper panel). The SWAS voltammograms (Fig. 6.18, lower panel) show for the hybrid film (Fig. 6.18C) no overlapping of the broad oxidation peak of PANI with the stripping peaks of the metal ions as noted for PANI-ES and oMMT LB films taken separately (Fig. 6.18A and B). The enhanced performance in the nanocomposite is most probably attributed to the stabilizing and ordering effect promoted by oMMT clay in PANI-ES Langmuir films leading to changes in the PANI-ES conformation chains, which may be enveloping oMMT layers, and then to more homogeneous LB films.

\section{CLAY/POLYTHIOPHENE NANOCOMPOSITES 5.1 Synthesis, Characterization, Morphology, and Potential Applications}

PT derivatives, particularly PEDOT, form an interesting class of conductive polymers because of the variety of properties such as relatively high electrical conductivity (up to $500 \mathrm{~S} / \mathrm{cm}$ ), transparency in the visible range, and excellent thermal and structural stability. For this reason they have also been investigated in view of making clay/PT nanocomposites with important technological applications. 


\section{CHAPTER 6 Clay/Conductive Polymer Nanocomposites}
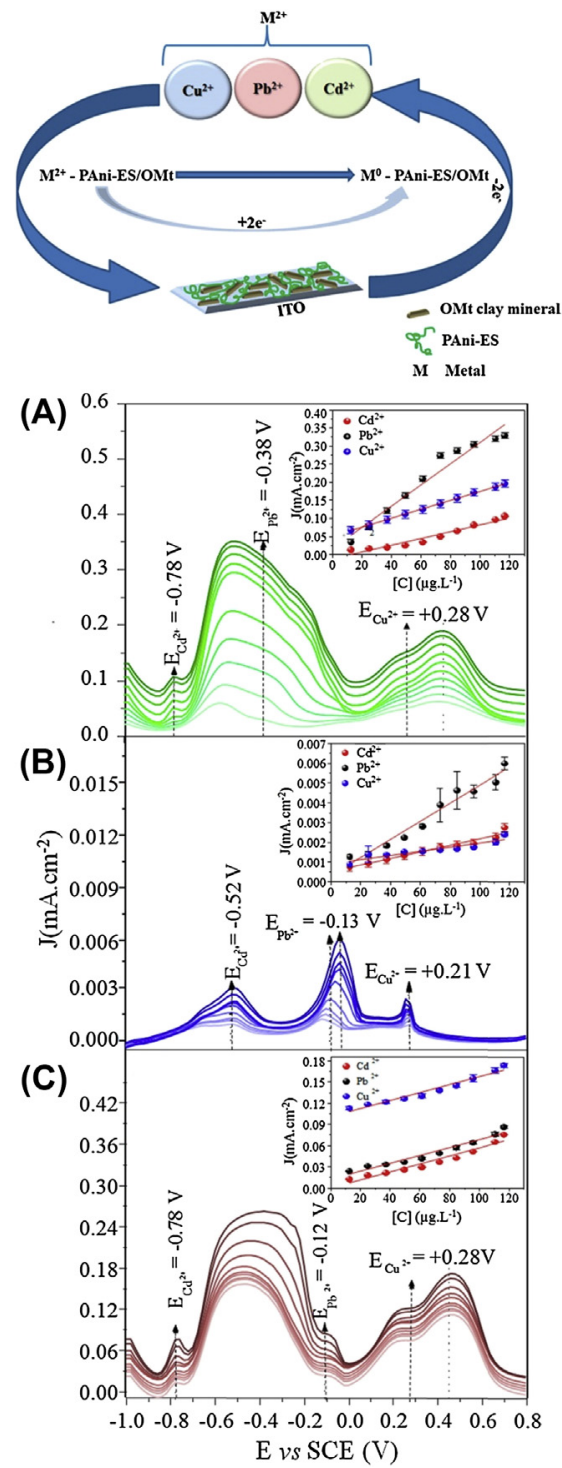

FIGURE 6.18 Upper panel: Mechanism of detection of metal ions with the Langmuir-Blodgett (LB films). Lower panel: Square wave anodic stripping voltammograms for simultaneous detection of $\mathrm{Cu}^{2+}$, $\mathrm{Pb}^{2+}$, and $\mathrm{Cd}^{2+}$. (A) Polyaniline-emeraldine salt Langmuir-Blodgett (PANI-ES LB) films. (B) Orgaomontmorillonite (OMMT) clay LB films. (C) PANI-ES/OMMT nanocomposite LB films. All the films had 20 layers deposited onto indium tin oxide (ITO) plates. Electrochemical conditions: solutions in $\mathrm{HCl} 0.1 \mathrm{M}$; deposition potential: $-1.0 \mathrm{~V}$; accumulation time of $300 \mathrm{~s}$; amplitude of $50 \mathrm{mV}$; frequency of $15 \mathrm{~Hz}$. ITO, indium tin oxide. Reproduced with permission of ACS from A. de Barros, M. Ferreira, C.J.L. Constantino, J.R. Ribeiro Bortoleto, M. Ferreira, ACS Appl. Mater. Interfaces 7 (2015) 6828-6834. 


\subsubsection{Oxidative Polymerization}

PEDOT is one of the most investigated conducting polymers because of its relatively high conductivity in the doped state $(500-1000 \mathrm{~S} / \mathrm{cm})$ and remarkable thermal stability. However, a significant problem in the practical uses of PEDOT is related to the infusible character of the material as well as to its poor solubility. Good aqueous dispersions of PEDOT using poly(styrene sulfonate) (PSS) as dopant constitute the usual way to supply this polymer as PEDOT:PSS [68]. Oxidative polymerization can be conducted in three synthetic approaches: (1) intercalation of 3,4-ethylenedioxythiophene (EDOT) and in-situ polymerization, (2) clay expansion and in-situ oxidative polymerization of EDOT, and (3) direct intercalation of PEDOT from PEDOT:PSS (Fig. 6.19).

Organomodified clays can be prepared using a range of cationic surfactants; among them octadecylamine salt has been adopted to successfully fabricate the exfoliated oMMT/PEDOT nanocomposites by in-situ polymerization in aqueous media. Hydrochloric acid, 1,5-naphthalenedisulfonic acid, and sodium benzenesulfonate have been employed to trigger the polymerization of 3,4-ethylenedioxythiophene by offering active sites on the layers of MMT [69].

Similarly, a composite of proton-exchanged Maghnite-H (an Algerian MMT-type clay) and PEDOT was prepared by in-situ chemical polymerization of the 3,4-ethylenedioxythiophene, without the use of solvent or

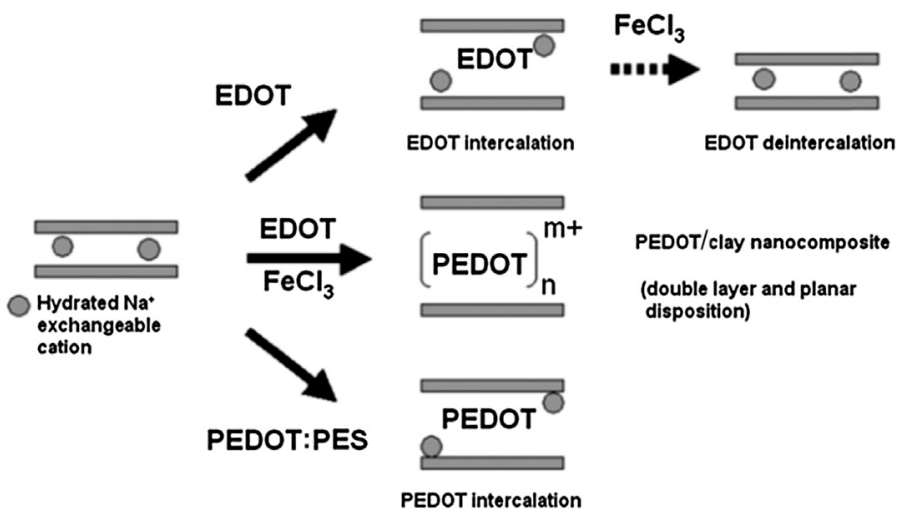

FIGURE 6.19 Idealized processes of interaction of 3,4-ethylenedioxythiophene (EDOT) and poly(3,4-ethylenedioxythiophene) (PEDOT) with Na-montmorillonite following the three synthetic approaches (from top to bottom): intercalation of EDOT and in-situ polymerization; clay expansion and in-situ oxidative polymerization of EDOT; direct intercalation of PEDOT. Scheme based on data previously published in S. Letaıef, P. Aranda, R. Fernandez-Saavedra, J.C. Margeson, C. Detellier, E. Ruiz-Hitzky, J. Mater. Chem. 18 (2008) 2227-2233. 


\section{CHAPTER 6 Clay/Conductive Polymer Nanocomposites}

oxidant. Formation of Maghnite-H-separated plates indicates partial exfoliation of the clay upon synthesis of the nanocomposite (Fig. 6.20) [70].

Synthesis of clay/PT nanocomposites was achieved in high-yield polymerization of thiophene in the presence of pristine MMT without any externally added oxidant $\left(\mathrm{FeCl}_{3}\right)$. Ballav et al. [71] have succeeded in preparing composites by solvent-free direct reaction between the monomer and MMT-Na ${ }^{+}$. The composites produced showed that the PT was intercalated in the interlayer space and that the resultant material showed a modest but nonzero electronic conductivity on the order of $10^{-4} \mathrm{~S} / \mathrm{cm}$.

A hybrid nanocomposite was prepared by graft copolymerization of thiophene onto a PS backbone by a multistep approach. The graft copolymerization of thiophene monomers onto PS was initiated after addition of ferric chloride $\left(\mathrm{FeCl}_{3}\right)$ oxidant, therefore providing $\mathrm{FeCl}_{3}$-doped PT chemically grafted to PS chains [72]. Khalfaoui-Boutoumi et al. [73] reported
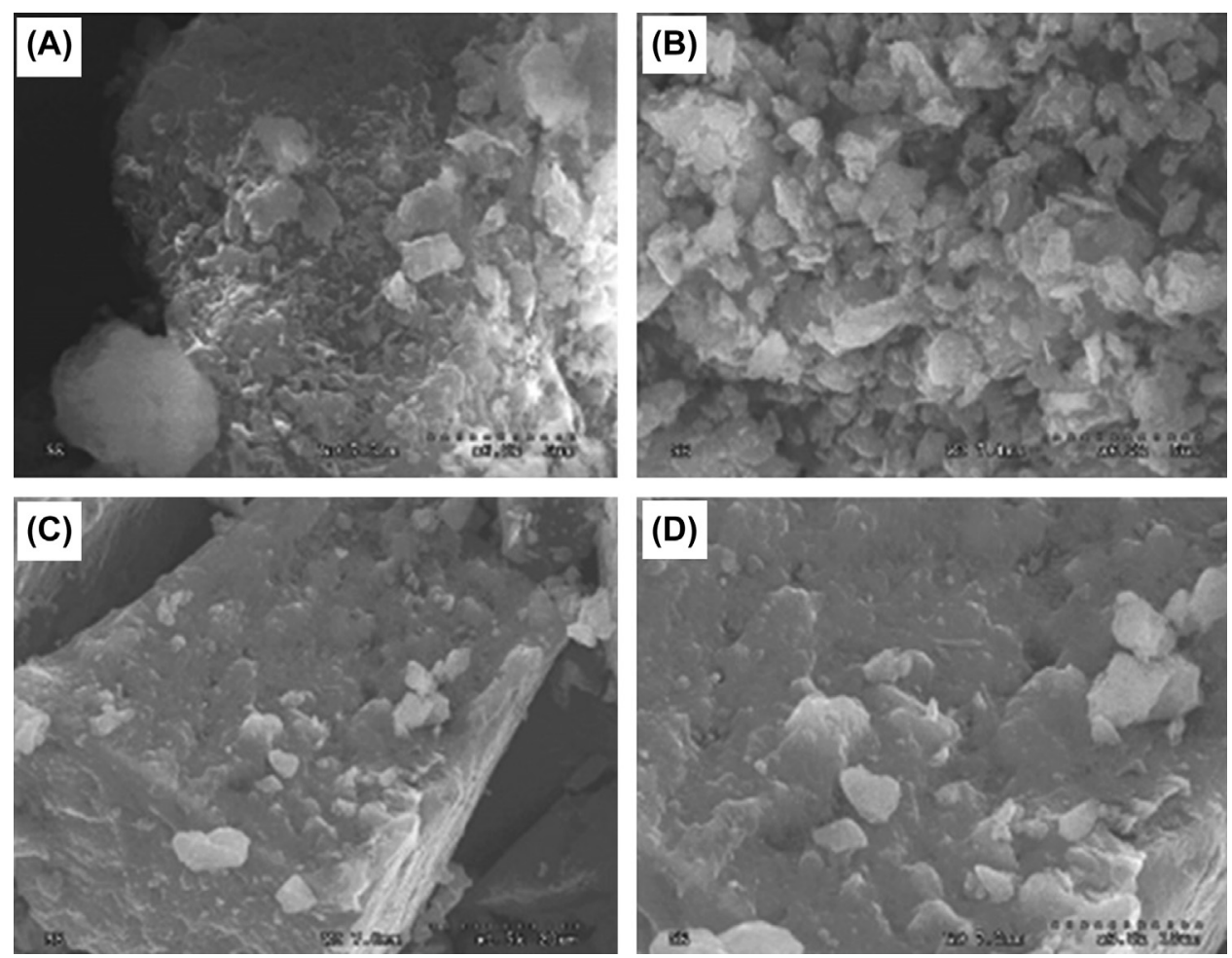

FIGURE 6.20 Scanning electron micrograph images of Maghnite-H (A) hybrids Maghnite-H-poly(3,4-ethylenedioxythiophene) (PEDOT) (B) obtained with 50\% Maghnite-H, $24 \mathrm{~h}, 90^{\circ} \mathrm{C}$, and Maghnite-H-PEDOT (C and D) obtained with 10\% Maghnite-H, $96 \mathrm{~h}, 90^{\circ} \mathrm{C}$, with a work distance of $7.0-7.4 \mathrm{~mm}$ and an amplifcation of 1.5-6.0 k. Reproduced from A. Megherbi, R. Meghabar, M. Belbachir, J. Surf. Eng. Mater. Adv. Technol. 3 (2013) 21-27. 
the preparation of the hybrid material $\mathrm{TiO}_{2}-\mathrm{MMT} / \mathrm{PT}-\mathrm{SDS}$ by the in-situ chemical oxidative polymerization of thiophene in the presence of the anionic surfactant SDS, into the matrix of $\mathrm{TiO}_{2}-\mathrm{MMT}$ at a thiophene/ $\left(\mathrm{TiO}_{2}-\mathrm{MMT}\right)$ mass ratio of 0.2 . The end hybrid material $\mathrm{TiO}_{2}-\mathrm{MMT} /$ PT20\%-SDS was found to act as a sono-, photo-, and sonophotocatalyst of the degradation of rhodamine 6G (R6G). Interestingly, Fig. 6.21 shows that photodegradation of the dye was relatively rapid under ultrasonic action in the presence of the catalyst, which attained a maximum dye removal of $96 \%$, that is, under sonophotocatalysis conditions [ultrasonic degradationsimulation sun test (US-ST)]. There is thus a synergetic effect of ultrasound and simulated sunlight, in contrast to the reference hybrid photocatalyst $\mathrm{TiO}_{2}-\mathrm{MMT}$ and $\mathrm{TiO}_{2}-\mathrm{P} 25$ (commercial catalyst), which did not exhibit any synergetic effects of sonocatalysis and photocatalysis of the dye degradation. In the presence of $\mathrm{TiO}_{2}-\mathrm{P} 25$, no synergy was observed between sonocatalysis and photocatalysis. The rate constant of the sonophotocatalytic and sonocatalytic degradation was almost equal and the dye degradation attained only $32.4 \%$ and $29 \%$, respectively. A similar behavior was observed with the $\mathrm{TiO}_{2}-\mathrm{MMT}$ catalyst at the same experimental conditions, but compared to the results obtained in the presence of $\mathrm{TiO}_{2}-\mathrm{P} 25$, the rate

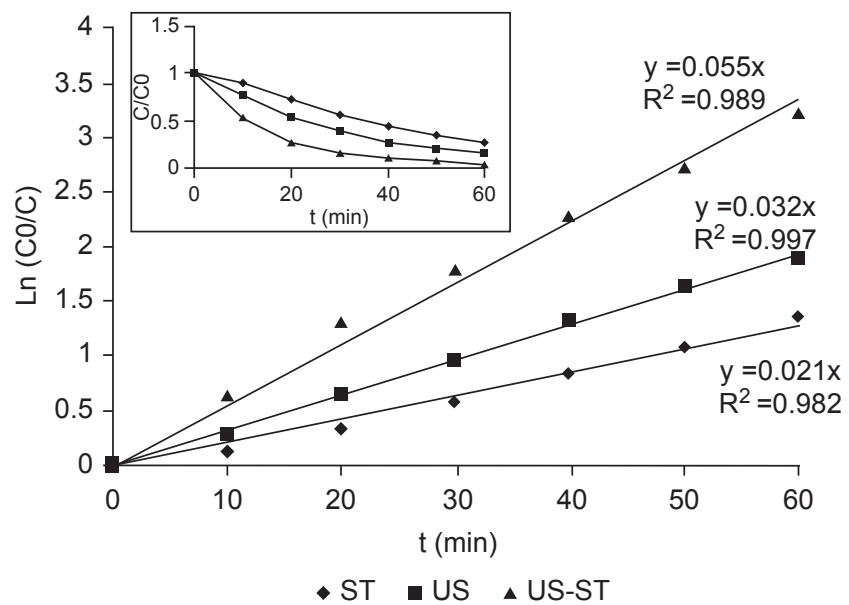

FIGURE 6.21 Kinetic analysis for each R6G degradation process (ST, US, and US-ST) with an R6G concentration of $125 \mathrm{ppm}$ at room temperature and natural pH (pH 5.1) in the presence of $\mathrm{TiO}_{2}-$ montmorillonite (MMT)/PT20\%—SDS and with $0.5 \mathrm{~g} / \mathrm{L}$ of $\mathrm{TiO}_{2}$ in the catalyst $\left(\mathrm{TiO}_{2}-\mathrm{MMT} / \mathrm{PT} 20 \%\right.$ -SDS) considering a pseudo-first-order reaction. The corresponding removal with the degradation time is given in the inset panels ST, simulation sun test; US, ultrasonic degradation; US-ST, combination of sonocatalysis and photocatalysis. Reproduced with permission of Elsevier from N. Khalfaoui-Boutoumi, $H$. Boutoumi, H. Khalaf, B. David, Appl. Clay. Sci. 80-81 (2013) 56-62. 
constants and dye removal percentage were high using each process alone (ST and US).

\subsubsection{Electropolymerization}

The preparation of exfoliated PEDOT-MMT nanocomposites by electropolymerization in aqueous solution has been reported by Aradilla et al. [74]. MMT was first dispersed for $24 \mathrm{~h}$ and then EDOT was added and electropolymerized. The nanocomposites were prepared with MMT at 0 (EDOT in the absence of MMT), 1, 5, and 10\% w/w relative to EDOT. The conductivity change was marginal as it decreased from $5.5 \mathrm{~S} / \mathrm{cm}$ to $3.8,2.7$, and $1.3 \mathrm{~S} / \mathrm{cm}$ upon incorporation of MMT at 1,5 , and $10 \% \mathrm{w} / \mathrm{w}$. The electroactivity of PEDOT-MMT nanocomposites, which increases with the concentration of clay, is higher than that of individual PEDOT, whereas the electrostability is only slightly lower for the former than for the latter. Similarly, a composite with concentrations of clay ranging from $5 \% \mathrm{w} / \mathrm{w}$ to $50 \% \mathrm{w} / \mathrm{w}$ have been prepared. The resulting composites were found to be suitable for ultracapacitor devices (Fig. 6.22) [75].

\subsubsection{Sonochemical Polymerization}

Polymer-clay nanocomposites based on PEDOT:PSS and MMT were synthesized by sonochemical polymerization [76]. PEDOT:PSS was water dispersible because of the PSS dopant. Sodium dodecylbenzene sulfonate and ionic liquid were used to increase the interlayer spacing and the conductivity of the nanocomposites, respectively. Different routes have been explored to fabricate conductive-coated nanoclays. Using surfactant along with ionic liquid resulted in a good basal spacing $\left(d_{\mathrm{L}}\right)$ and also a good electrical conductivity. Surfactant not only helped in the dispersion of clay but also made it possible for the ionic liquid to form a microemulsion in water.

Kuila et al. [77] reported the synthesis of clay/PT nanocomposites by sonochemical polymerization: poly(3-dodecyl thiophene) (P3DDT)/organically modified MMT are prepared using the melt-cooled procedure and by solvent cast. MMT/poly(3-hexyl thiophene) were also prepared in the melt-cooled state [78] and by solvent casting [79]. In the case of P3DDT, conductivity was the highest for the regioregular polymer upon doping with $\mathrm{I}_{2}$. For the undoped P3DDT, the regular P3DDT is again more conductive than the irregular one. The melt-cooled samples of the irregular P3DDT exhibited a slightly higher conductivity than the same polymer 

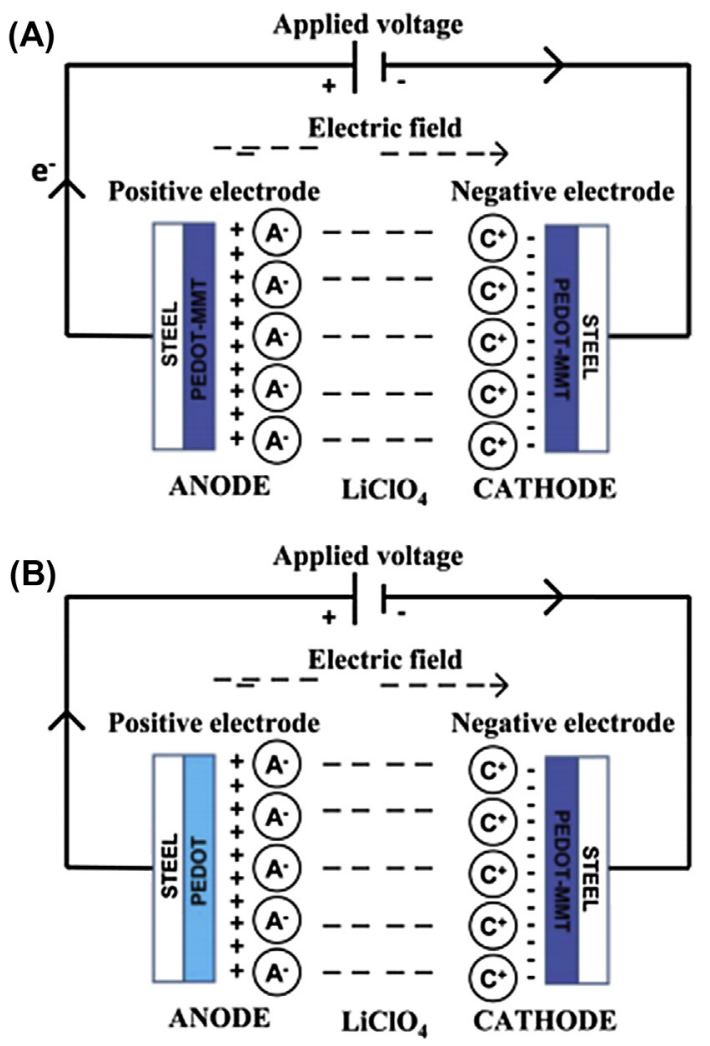

FIGURE 6.22 Scheme of the type I (A) and type II (B) ultracapacitors. Reproduced with permission of RSC from D. Aradilla, D. Azambuja, F. Estrany, M.T. Casas, C.A. Ferreira, C. Aleman, J. Mater. Chem. 22 (2012) 13110-13122.

prepared by solvent casting. All samples exhibit progressive decrease of conductivity for increasing mass loading of clay.

\subsubsection{Self-assembly}

Mäkiniem et al. [80] reported the synthesis of electrically and ionically conducting nacre-mimetic nanocomposites using synthetic nanoclay, PEDOT:PPS, and a poly(ionic liquid) polymer from aqueous dispersions (Fig. 6.23). The nanocomposites exhibit high degrees of mesoscale order and mechanical robustness in the sense that they have both high stiffness and strength. Electrical conductivity of PEDOT:PSS is 


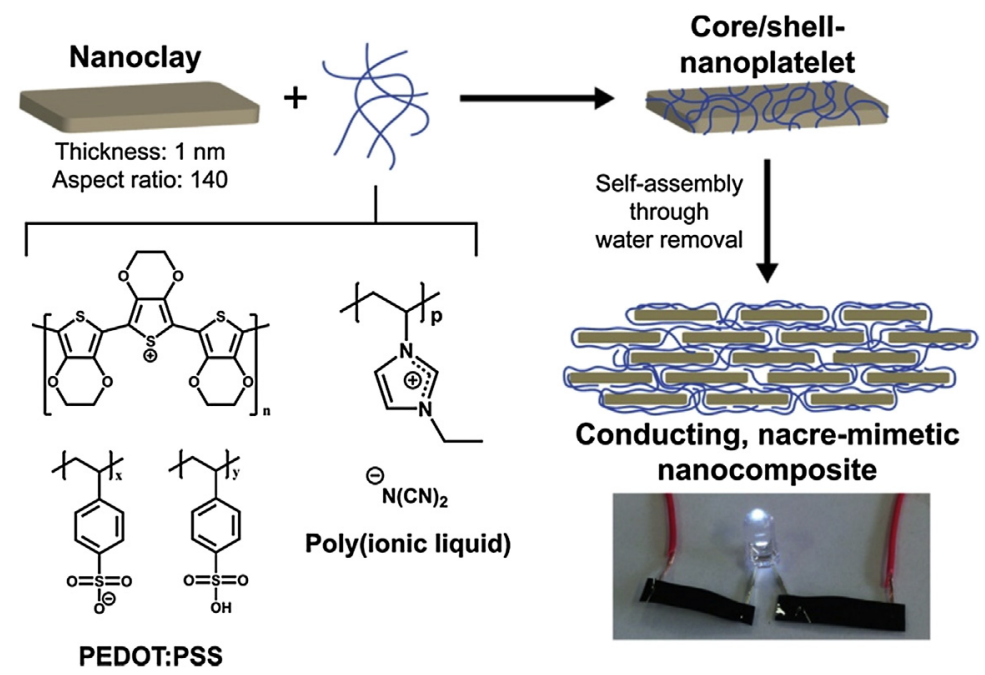

FIGURE 6.23 General approach for the waterborne self-assembly of nacre-mimetic films based on Sumecton (SUM) nanoclay and conducting polymers. PEDOT:PSS = poly(3,4-ethylenedioxythiophene): polystyrenesulfonate; poly(ionic liquid) $=$ poly(1-ethyl-3 vinylimidazolium dicyanamide). The photograph at the bottom right shows an LED connected via conducting PEDOT:PSS/SUM nacremimetics and powered at $3.5 \mathrm{~V}$. Reproduced with permission of ACS from R.O. Mäkiniemi, P. Das, D. Hönders, K. Grygiel, D. Cordella, C. Detrembleur, J. Yuan, A. Walther, ACS Appl. Mater. Interfaces 7 (2015)15681-15685.

$440 \mathrm{~S} / \mathrm{cm}$ and the clay/PEDOT:PSS has a conductivity of $250 \mathrm{~S} / \mathrm{cm}$, which was raised to $560 \mathrm{~S} / \mathrm{cm}$ after tempering the nacre-mimetic at $200^{\circ} \mathrm{C}$. This was ascribed to the orientation of conducting domains favored by the nanoconfinement of the polymer. The authors also noted a dramatic increase of the $d_{001}$ from 1.23 to $2.08 \mathrm{~nm}$ on going from the clay to the nanocomposite.

\subsubsection{Summary of Synthesis Conditions and Properties of Selected Clay/Polythiophene and Clay/PEDOT Nanocomposites}

Table 6.3 reports the synthesis conditions and physicochemical characteristics of selected clay/PT nanocomposites prepared by oxidative polymerization, electropolymerization, and sonochemical polymerization in the presence of clay. 
Table 6.3 Summary of Preparation Methods and Electrical and Morphological Properties of Clay/Polythiophene Nanocomposites

\begin{tabular}{|c|c|c|c|c|c|c|c|c|}
\hline Polythiophene/Clay & Clay & $\begin{array}{l}\text { Coupling or } \\
\text { Intercalating Agent }\end{array}$ & $\begin{array}{l}\text { Other } \\
\text { Component }\end{array}$ & Structure & Mass Loading & $\sigma(\mathrm{S} / \mathrm{cm})$ & $\begin{array}{l}\text { Potential } \\
\text { Application }\end{array}$ & References \\
\hline \multicolumn{9}{|c|}{ In-Situ Oxidative Polymerization $\mathrm{FeCl}_{3}$} \\
\hline $\begin{array}{l}\text { PEDOT/montmorillonite } \\
\text { (MMT) }\end{array}$ & MMT [MMT (SWy-2)] & - & - & Intercalated & $\begin{array}{l}3 \mathrm{~g}(\mathrm{SWy}-2) / 300 \mathrm{~mL} \\
1.3 \mathrm{~g} \mathrm{EDOT}\end{array}$ & $5.10^{-4} \mathrm{~S} / \mathrm{cm}$ & Conductive films & [68] \\
\hline
\end{tabular}

Direct Intercalation of Poly(3,4-Ethylenedioxythiophene) (PEDOT) From an Aqueous Dispersion of it Doped With Polystyrene Sulfonate

\begin{tabular}{|c|c|c|c|c|c|c|c|c|}
\hline PEDOT/MMT & MMT (SWy-2) & - & - & Intercalated & $\begin{array}{l}1 \mathrm{~g}(\mathrm{SWy}-2) / 100 \mathrm{~mL} \\
1.0 \mathrm{~g} \text { PEDOT:PSS }\end{array}$ & $5.10^{-4} \mathrm{~S} / \mathrm{cm}$ & Conductive films & [68] \\
\hline \multicolumn{9}{|c|}{ Intercalation of 3,4-Ethylenedioxythiophene (EDOT) and In-Situ Polymerization } \\
\hline \multirow[t]{2}{*}{ PEDOT/MMT } & MMT (SWy-2) & - & - & Intercalated & $\begin{array}{l}\text { (i) } 3 \mathrm{~g}(\mathrm{SWy}-2) / \\
300 \mathrm{~mL} \\
1.3 \mathrm{~g} \mathrm{EDOT}\end{array}$ & $5.10^{-4} \mathrm{~S} / \mathrm{cm}$ & & [68] \\
\hline & & & & & $\begin{array}{l}\text { (ii) } 1.0 \mathrm{~g} \text { of the } \\
\text { intercalate EDOT- } \\
\mathrm{SWy}-2100 \mathrm{~mL} \\
\text { aqueous solution of } \\
\mathrm{Fe}(\mathrm{III})\end{array}$ & & & \\
\hline
\end{tabular}

In-Situ Anodic Polymerization

\begin{tabular}{|c|c|c|c|c|c|c|c|c|}
\hline PEDOT/MMT & MMT & - & - & Exfoliated & $\begin{array}{l}5 \% \text { to } 50 \% \mathrm{w} / \mathrm{w} \text { (dry } \\
\text { weight) }\end{array}$ & $5.5 \mathrm{~s} / \mathrm{cm}$ & $\begin{array}{l}\text { Ultracapacitor } \\
\text { devices }\end{array}$ & [75] \\
\hline \multicolumn{9}{|c|}{ Anodic Electropolymerization } \\
\hline PEDOT & Bentonite & - & - & Exfoliated & $1 \%$ to $10 \% \mathrm{w} / \mathrm{w}$ & $5.6 \mathrm{~S} / \mathrm{cm}$ & $\begin{array}{l}\text { Electrochemical } \\
\text { application }\end{array}$ & [74] \\
\hline
\end{tabular}

In-Situ Polymerization (Hydrochloric Acid, 1,5-Naphthalenedisulfonic Acid, and Sodium Benzenesulfonate Have Been Employed to Activate the Polymerization of 3,4-Ethylenedioxythiophene)

\begin{tabular}{|lllllll}
\hline oMMT/PEDOT & $\begin{array}{l}\text { MMT, organically } \\
\text { modified by } \\
\text { octadecylamine salt }\end{array}$ & Octadecylamine salt & - & Exfoliated & $\begin{array}{l}\text { OMMT (0.1 g): } \\
\text { EDOT } \\
\text { monomer }=1 \mathrm{mmol} \\
\mathrm{V}=20 \mathrm{~mL}\end{array}$ & $\begin{array}{l}10^{-7} \text { to 10 } \\
-2\end{array}$ \\
\hline In-Situ Chemical Polymerization & & & $\begin{array}{l}\text { Electrical } \\
\text { conductivity }\end{array}$ \\
\hline $\begin{array}{l}\text { Clay (Maghnite-H)/ } \\
\text { PEDOT }\end{array}$ & Maghnite-H & - & - & Intercalated & $\begin{array}{l}10 \% \text { by weight of } \\
\text { Maghnite-H/ } \\
\text { monomer }\end{array}$ & - \\
\hline
\end{tabular}




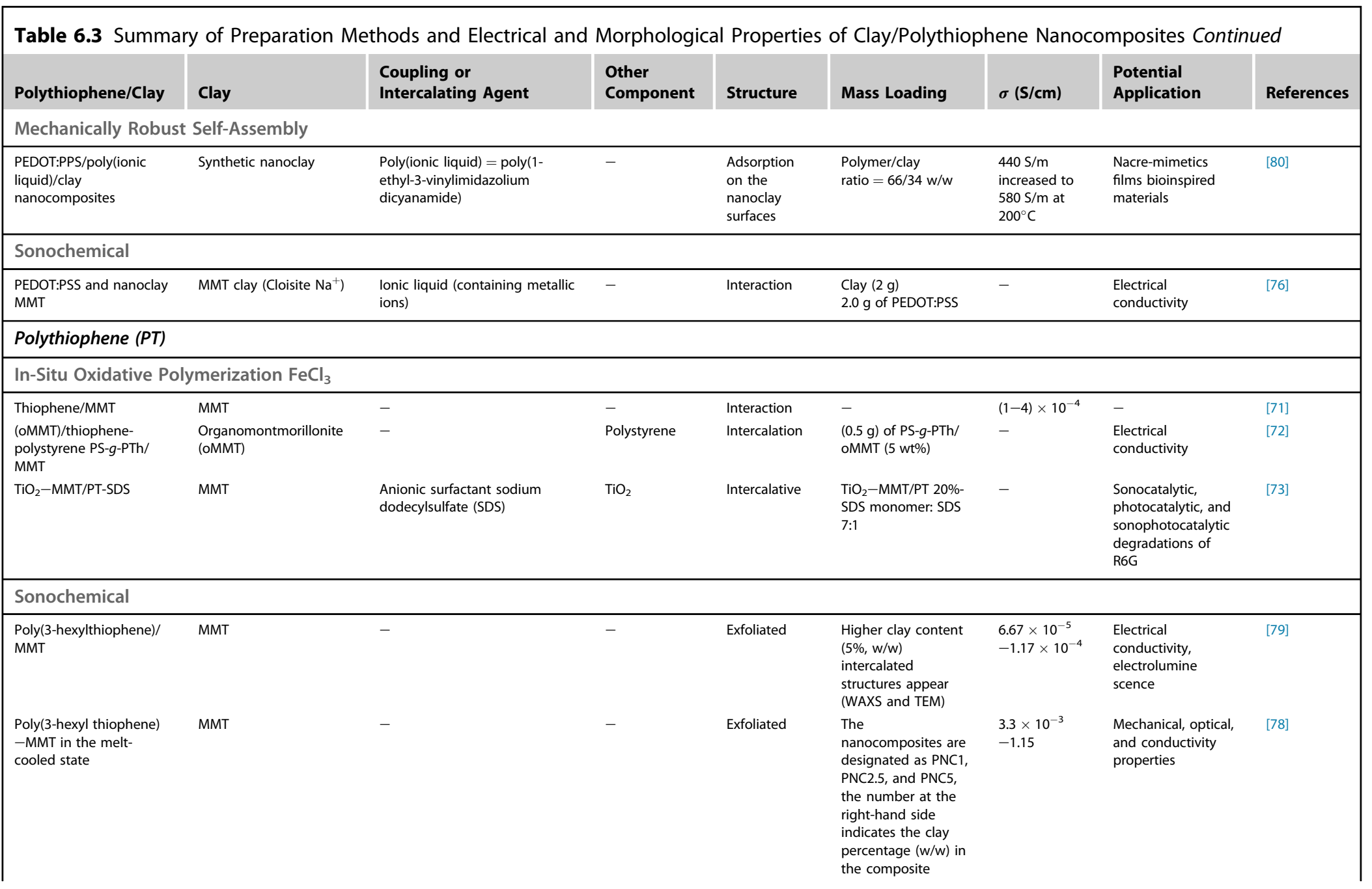




\begin{tabular}{|c|c|c|c|c|c|c|c|c|}
\hline \multicolumn{9}{|c|}{ Solvent-Cast and Melt-Cooled Procedures } \\
\hline $\begin{array}{l}\text { Poly(3-dodecyl } \\
\text { thiophene) - organically } \\
\text { modified MMT clay }\end{array}$ & MMT & & & Exfoliated & $\begin{array}{l}\text { The solvent cast } \\
\text { P3DDT1-om-clay } \\
\text { nanocomposite } \\
\text { exhibit exfoliated } \\
\text { clay structure below } \\
2.5 \%(w / w)\end{array}$ & - & & [77] \\
\hline \multicolumn{9}{|c|}{ In-Situ Polymerization (PHDT/oMMT) and by the Solvent-Casting Method } \\
\hline $\begin{array}{l}\text { Poly(3- } \\
\text { hexadecylthiophene) } \\
\text { (PHDT) with MMT }\end{array}$ & $\begin{array}{l}\text { MMT clay, Brasgel A, } \\
\text { from Bentonit, Brazil, } \\
\mathrm{Na}^{+} \text {form (MMT), } \\
\text { (oMMT), Claytone-40, } \\
\text { USA, }\end{array}$ & & & $\begin{array}{l}\text { Mostly } \\
\text { exfoliated (in- } \\
\text { situ } \\
\text { polymerized } \\
\text { MMT, } \\
\text { obtained by } \\
\text { solvent } \\
\text { casting, is an } \\
\text { intercalated } \\
\text { nanocompo } \\
\text { site) }\end{array}$ & MMT clay $(5 \%)$ & - & - & [81] \\
\hline \multicolumn{9}{|c|}{ Latex - Colloid Interaction $=$ Mixture } \\
\hline $\begin{array}{l}\text { Polypyrrole/ } \\
\text { polythiophene/MMT }\end{array}$ & MMT & $\begin{array}{l}\text { Sodium dodecylbenzene sul- } \\
\text { fonate }\end{array}$ & Polypyrrole & Interaction & & - & & [82] \\
\hline \multicolumn{9}{|c|}{ In-Situ Oxidative Polymerization } \\
\hline $\begin{array}{l}\text { Organophilic clay/poly(3- } \\
\text { hexylthiophene) }\end{array}$ & MMT & $\begin{array}{l}\text { Tetradecyltrimethylammonium } \\
\text { chloride }\end{array}$ & - & & 1 wt $\%$ clay & - & $\begin{array}{l}\text { Electrochemical } \\
\text { corrosion gas } \\
\text { barrier }\end{array}$ & [83] \\
\hline
\end{tabular}




\section{CONCLUSION}

Materials science has witnessed dynamic research on clay/conductive polymer nanocomposites since the mid-1980s. This chapter does not intend to be an exhaustive review of the literature over the last three decades but rather to describe the main strategies to design clay nanocomposites of the most investigated, inherently conductive polymers, namely, PPy, PANI, and PT including PEDOT:PSS. Conductive polymers not only impart electrical conductivity because of their conductive nature, but are themselves relatively high surface area polymers compared to traditional, insulating polymers. This ensures they have high surface area clay nanocomposites, which is beneficial for all applications where surface area is needed. This is the case of (bio)sensors, catalysts, and fillers among other materials.

As in previous chapters, it is needless to say that premodification of clays is an essential step to successfully enhance intercalation or eventually exfoliation by the conductive polymers. Throughout this chapter, we have stressed the essential role of surfactants, reactive diazonium, and silanes in providing adhesive clay sheets for the conductive polymers once their synthesis by any means is triggered. Taking PPy as an example, it is a hydrophobic conductive polymer that adheres much better to hydrophobic materials, hence the essential role of the organomodification of clays.

Concerning the benefits of designing intercalated or exfoliated nanocomposites, the latter were demonstrated usually to exhibit superior properties compared to the intercalated ones. It is thus clear that new strategies should be envisioned to successfully design exfoliated nanocomposites.

Through selected past and recent applications, it is clear that academic research into clay/conductive polymer nanocomposites will continue to grow because these materials combine the best of two worlds: low-cost abundant minerals with remarkable nanostructural properties and nanostructuring abilities, on the one hand and ease of synthesis, reactivity, and electrical conductivity of conjugated polymers, on the other hand.

\section{REFERENCES}

[1] H. Shirakawa, E.J. Louis, A.G. MacDiarmid, C.K. Chiang, A.J. Heeger, J. Chem. Soc. Chem. Commun. (1977) 578-580.

[2] A.G. MacDiarmid, Chemistry (2000) 427-447.

[3] T.A. Skotheim, J.R. Reynolds, Handbook of Conducting Polymers, third ed., CRC Press, Boca Raton, 2007. 
[4] N.G. Gaylord, H. Ender, L. Davis Jr., A. Takahashi, Modification of polymers, in: C.E. Carraher, M. Tsuda (Eds.), ACS Symposium Series, American Chemical Society, Washington, DC, 1980, pp. 469-475.

[5] P.K. Pal, S.K. De, Rubber Chem. Technol. 56 (1983) 737-773.

[6] D. Porter, E. Metcalfe, M.J.K. Thomas, Fire Mater. 24 (2000) 45-52.

[7] K.A. Carrado, Appl. Clay Sci. 17 (2000) 1-23.

[8] F.R.F. Fan, A.J. Bard, J. Electrochem. Soc. 133 (1986) 301-304.

[9] M. Omastová, M. Trchová, J. Kováŕvá, J. Stejskal, Synth. Met. 138 (2003) 447-455.

[10] M. Biswas, S.S. Ray, Adv. Polym. Sci. 155 (2001) 167-221.

[11] M. Omastová, M. Mravčáková, I. Chodák, J. Pionteck, L. Haussler, Polym. Eng. Sci. 46 (2006) 1069-1078.

[12] K. Jlassi, S. Chandran, M. A Poothanari, M. Benna-Zayani, S. Thomas, M.M. Chehimi, Langmuir 32 (2016) 3514-3524.

[13] K. Jlassi, A. Singh, D.K. Aswal, R. Losno, M. Benna-Zayani, M.M. Chehimi, Colloids Surf. A 439 (2013) 193-199.

[14] L. Zang, J. Qiu, C. Yang, E. Sakai, Sci. Rep. 6 (2016) 20470, http://dx.doi.org/ 10.1038/ srep20470.

[15] A. de Barros, M. Ferreira, C.J.L. Constantino, J.R. Ribeiro Bortoleto, M. Ferreira, ACS Appl. Mater. Interfaces 7 (2015) 6828-6834.

[16] Y. Kong, H. Ge, J. Xiong, S. Zuo, Y. Wei, C. Yao, L. Deng, Appl. Clay Sci. 99 (2014) 119-124.

[17] M. Mravčáková, K. Boukerma, M. Omastová, M.M. Chehimi, Mater. Sci. Eng. C 26 (2006) 306-313.

[18] M.A. Breimer, G. Yevgeny, S. Sy, O.A. Sadik, Nano Lett. 1 (2001) 305-308.

[19] A. Mekki, N. Joshi, A. Singh, Z. Salmi, P. Jha, P. Decorse, S. Lau-Truong, R. Mahmoud, M.M. Chehimi, D.K. Aswal, S.K. Gupta, Org. Electron. 15 (2014) 71-81.

[20] B.A. Bhanvase, S.H. Sonawane, Chem. Eng. Process. Process. Intensif. 85 (2014) 86-107.

[21] S. Sadki, P. Schottland, N. Brodie, G. Sabouraud, Chem. Soc. Rev. 29 (2000) 283-293.

[22] M. Trueba, A.L. Montero, J. Rieumont, Electrochim. Acta 49 (2004) 4341-4349.

[23] S. Cosnier, S. Da Silva, D. Shan, K. Gorgy, Bioelectrochemistry 74 (2008) 47-51.

[24] S.H. Cho, K.T. Song, J.Y. Lee, Recent Advances in Polypyrrole, in Ref. 3, pp. 8.1-8.87 (Chapter 8).

[25] X.-G. Li, A. Li, M.-R. Huang, Y. Liao, Y.-G. Lu, J. Phys. Chem. C 114 (2010) 19244-19255.

[26] L.F.B.L. Pontes, J.E.G. de Souza, A. Galembeck, C.P. de Melo, Sens. Actuators B 177 (2013) 1115-1121.

[27] S. Letaïef, P. Aranda, E. Ruiz-Hitzky, Appl. Clay Sci. 28 (2005) 183-198.

[28] M. Zahra, S. Zulfiqar, C.T. Yavuz, H.-S. Kweon, M.I. Sarwar, Compos. Sci. Technol. 100 (2014) 44-52.

[29] K. Boukerma, J.-Y. Piquemal, M.M. Chehimi, M. Mravčáková, M. Omastová, P. Beaunier, Polymer 47 (2006) 569-576.

[30] J.W. Kim, F. Liu, H.J. Choi, S.H. Hong, J. Joo, Polymer 44 (2003) 289-293.

[31] M. Abbasian, B. Massomi, B. Rashidzadeh, H. Bahrami, J. Exp. Nanosci. 10 (2015) 844-858. 
[32] R.A. de Barros, M.C.C. Areias, W.M. de Azevedo, Synth. Met. 160 (2010) 61-64.

[33] M.F. Attia, T. Azib, Z. Salmi, A. Singh, P. Decorse, N. Battaglini, H. Lecoq, M. Omastová, A.A. Higazy, A.M. Elshafei, M.M. Hashem, M.M. Chehimi, J. Colloid Interface Sci. 393 (2013) 130-137.

[34] F.F. Fang, H.J. Choi, J. Joo, J. Nanosci. Nanotechnol 8 (2008) 1559-1581.

[35] M. Omastová, M. Mičušík, Chem. Pap. 66 (2012) 392-414.

[36] R.M.G. Rajapakse, K. Murakami, H.M.N. Bandara, R.M.M.Y. Rajapakse, K. Velauthamurti, S. Wijeratne, Electrochim. Acta 55 (2010) 2490-2497.

[37] I.D. Norris, B.R. Mattes, Conducting Polymer Fiber Production and Applications, in Ref. 3, pp. 2.1-2.72 (Chapter 2).

[38] J. Huang, R.B. Kaner, Polyaniline Nanofibers: Syntheses, Properties, and Applications, in Ref. 3, pp. 7.1-7.49 (Chapter 7).

[39] X. Zhang, L. Ji, S. Zhang, W. Yang, J. Power Sources 173 (2007) 1017-1023.

[40] B.K. Sharma, A.K. Gupta, N. Khare, S.K. Dhawan, H.C. Gupta, Synth. Met. 159 (2009) 391-395.

[41] S. Ameen, M. Shaheer Akhtar, S.G. Ansari, O.B. Yang, H.-S. Shin, Superlattices Microstruct. 46 (2009) 872-880.

[42] S. Sathiyanarayanan, S. Syed Azim, G. Venkatachari, Synth. Met. 157 (2007) 205-213.

[43] C. Barbero, M.C. Miras, B. Schnyder, O. Hass, R. Kötz, J. Mater. Chem. 4 (1994) 1775-1783.

[44] H. Tai, Y. Jiang, G. Xie, J. Yu, X. Chen, Z. Ying, Sens. Actuators B Chem. 129 (2008) 319-326.

[45] W. Jia, E. Segal, D. Kornemandel, Y. Lamhot, M. Narkis, A. Siegmann, Synth. Met. 128 (2002) 115-120.

[46] C. Peng, S. Zhang, D. Jewell, G.Z. Chen, Prog. Nat. Sci. 18 (2008) 777-788.

[47] A. Olad, M. Barati, H. Shirmohammadi, Prog. Org. Coat. 72 (2011) 599-604.

[48] M. Culebras, C.M. Gómez, A. Cantarero, Materials 7 (2014) 6701-6732.

[49] P.S. Rao, D.N. Sathyanarayana, in: H.S. Nalwa (Ed.), Advanced Functional Molecules and Polymers, Gordon \& Breach, Tokyo, 2001.

[50] S.-F. Chung, T.-C. Wen, A. Gopalan, Mater. Sci. Eng. B 116 (2005) 125-130.

[51] L. Li, J. Jiang, F. Xu, Mater. Lett. 61 (2007) 1091-1096.

[52] J. Stejskal, I. Sapurina, J. Prokes, J. Zemek, Synth. Met. 105 (1999) 195-202.

[53] Z. Gao, S. Rafea, L.H. Lim, Adv. Mater. 19 (2007) 602-606.

[54] S. Uemura, M. Yoshie, N. Kobayashi, T. Nakahira, Polym. J. 32 (2000) 987-990.

[55] K.H. Chen, S.M. Yang, Synth. Met. 135-136 (2003) 151-152.

[56] H. Van Hoang, R. Holze, Chem. Mater. 18 (2006) 1976-1980.

[57] R.G. Bavane, Synthesis and Characterization of Thin Films of Conducting Polymers for Gas Sensing Applications (Ph.D. thesis), North Maharashtra University, Jalagon (India), 2015.

[58] I.Y. Sapurina, M.A. Shishov, Oxidative polymerization of aniline: molecular synthesis of polyaniline and the formation of supramolecular structures, in: A. De Souza Gomes (Ed.), New Polymers for Special Applications, InTech, 2012, http:// dx.doi.org/10.5772/48758. Available from: http://www.intechopen.com/books/newpolymers-for-special-applications/oxidative-polymerization-of-aniline-molecularsynthesis-of-polyaniline-and-the-formation-of-supramol.

[59] A.A. Syed, M.K. Dinesan, Talanta 38 (1991) 815-837. 
[60] K. Jlassi, A. Mekki, M. Benna-Zayani, A. Singh, D.K. Aswal, M.M. Chehimi, RSC Adv. 4 (2014) 65213-65222.

[61] J. Gong, R.-N. Hua, Z.-W. Xie, S.-G. Wang, L.-Y. Qu, Polym. J. 33 (5) (2001) 377-382.

[62] H. Yan, M. Kajita, N. Toshima, Macromol. Mater. Eng 287 (2002) 503-508.

[63] H.S. Chae, W.L. Zhang, S.H. Piao, H.J. Choi, Appl. Clay Sci. 107 (2015) 165-172.

[64] I. Bekri-Abbes, E. Srasra, Mater. Sci. Semicond. Process 40 (2015) 543-549.

[65] I. Bekri-Abbes, E. Srasra, Mater. Sci. Semicond. Process 56 (2016) 76-82.

[66] S. Li, Y. Wei, Y. Kong, Y. Tao, C. Yao, R. Zhou, Synth. Met. 199 (2015) 45-50.

[67] A.H. Navarchian, M. Joulazadeh, F. Karimi, Prog. Org. Coat. 77 (2014) 347-353.

[68] S. Letaref, P. Aranda, R. Fernandez-Saavedra, J.C. Margeson, C. Detellier, E. RuizHitzky, J. Mater. Chem. 18 (2008) 2227-2233.

[69] Y. Han, Y. Lu, J. Appl. Polym. Sci. 111 (2009) 2400-2407.

[70] A. Megherbi, R. Meghabar, M. Belbachir, J. Surf. Eng. Mater. Adv. Technol. 3 (2013) 21-27.

[71] N. Ballav, M. Biswas, Synth. Met. 142 (2004) 309-315.

[72] M. Hatamzadeh, M. Jaymand, B. Massoumi, Polym. Int. 63 (2013) 402-412.

[73] N. Khalfaoui-Boutoumi, H. Boutoumi, H. Khalaf, B. David, Appl. Clay Sci. 80-81 (2013) 56-62.

[74] D. Aradilla, F. Estrany, D.S. Azambuja, M.T. Casas, J. Puiggali, C.A. Ferreira, C. Alemán, Eur. Polym. J. 46 (2010) 977-983.

[75] D. Aradilla, D. Azambuja, F. Estrany, M.T. Casas, C.A. Ferreira, C. Aleman, J. Mater. Chem. 22 (2012) 13110-13122.

[76] I. Ahmad, M. Hussain, K.-S. Seo, Y.-H. Choa, Synthesis and characterization of polymer-nanoclay conductive nanocomposites, J. Appl. Polym. Sci. 116 (2010) 314-319.

[77] B.K. Kuila, A.K. Nandi, J. Appl. Polym. Sci. 111 (2008) 155-167.

[78] B.K. Kuila, A.K. Nandi, J. Phys. Chem. B 110 (2006) 1621-1631.

[79] B.K. Kuila, A.K. Nandi, Macromolecules 37 (2004) 8577-8584.

[80] R.O. Mäkiniemi, P. Das, D. Hönders, K. Grygiel, D. Cordella, C. Detrembleur, J. Yuan, A. Walther, ACS Appl. Mater. Interfaces 7 (2015) 15681-15685.

[81] J.C. Macêdo-Fonsêca, I.S. Silva, R.M. Souto-Maior, Synth. Met. 59 (2009) 2215-2218.

[82] C.O. Oriakhi, M.M. Lerner, Mater. Res. Bull. 30 (1995) 723-729.

[83] Y.-H. Yu, C.-C. Jen, H.-Y. Huang, P.-C. Wu, C.-C. Huang, J.-M. Yeh, J. Appl. Polym. Sci. 91 (2004) 3438-3446. 